\title{
EXTREME F ACTIVITIES IN LATE PEGMATITIC EVENTS AS A KEY FACTOR FOR LILE AND HFSE ENRICHMENT: THE ÁNGEL PEGMATITE, CENTRAL ARGENTINA
}

\author{
MANUEL DEMARTIS ${ }^{\S}$ \\ CONICET - Departamento de Geología, Universidad Nacional de Río Cuarto, Ruta Nacional nº $36 \mathrm{~km} .601$ - (X5804BYA) \\ Río Cuarto, Argentina \\ JOAN CARLES MELGAREJO \\ Departament de Cristal•lografia, Mineralogia i Dipòsits Minerals, Universitat de Barcelona, C/Martí i Franqués s/n, \\ E-08028 Barcelona, Catalonia, Spain
}

FERNANDO COLOMBO

CONICET - Cátedra de Mineralogía, Facultad de Ciencias Exactas, Físicas y Naturales, Pabellón Geología, Universidad Nacional de Córdoba, Vélez Sarsfield 1611, (X5016GCA) Córdoba, Argentina

PURA ALFONSO

Departament d'Enginyeria Minera i Recursos Naturals, Universitat Politècnica de Catalunya, Av. De les Bases de Manresa 61-73, E-08242 Manresa, Catalonia, Spain

JoRGE ENRIQUE CONIGLIO

Departamento de Geología, Universidad Nacional de Río Cuarto, Ruta Nacional n 36 km. $601-($ X5804BYA)

Río Cuarto, Argentina

\section{Lucio Pedro PINOTTI ANd Fernando JaVIER D’ERAMO}

CONICET - Departamento de Geología, Universidad Nacional de Río Cuarto, Ruta Nacional n $36 \mathrm{~km} .601$ - (X5804BYA) Río Cuarto, Argentina

\begin{abstract}
The Ángel pegmatite forms part of the Comechingones pegmatitic field, in central Argentina, which is made up of pegmatites characterized by low to intermediate degrees of fractionation, classified as beryl-columbite-phosphate subtype pegmatites. These pegmatites are syntectonic with a regional shear zone. The Ángel pegmatite contains associations with quartz, microcline, plagioclase, a first generation of muscovite (muscovite I), beryl, members of the columbite group, triplite, and montebrasite. This association is locally affected by two stages of replacement. The first replacement stage is characterized by early albitization, followed by the development of associations of cleavelandite, quartz, Fe-rich elbaite (elbaite I), a second generation of muscovite (muscovite II), topaz, lacroixite, fluorapatite, pollucite, columbite-(Mn), and Hf-rich zircon. Muscovite II replaces montebrasite and muscovite $\mathrm{I}$, and is characterized by slight enrichments in $\mathrm{F}, \mathrm{Rb}$, and $\mathrm{Cs}$. The second replacement stage generated a new mineral association characterized by muscovite III, Fe-poor elbaite (elbaite II), Cs-micas, and U-rich hydroxykenomicrolite. Muscovite III replaces muscovite II and is characterized by strong enrichments in F, Cs, and, to a lesser extent, Rb. In turn, muscovite III is replaced by the Cs-micas sokolovaite and nanpingite. The high F content of the nanpingite suggests that this could be the F- analogue of nanpingite, which would be a new mineral. The sequence of replacement is indicative of an increase in the F activity in the latest pegmatitic fluids. The high $\mathrm{F}$ activity of these fluids favored the transport of $\mathrm{Ta}, \mathrm{U}, \mathrm{Bi}, \mathrm{Hf}, \mathrm{Rb}$, $\mathrm{Cs}$, and $\mathrm{Li}$, and the formation of F-rich micas could be the mechanism for precipitating these LILE and HFSE elements. The syntectonic emplacement of this pegmatite in a large shear zone could be a decisive factor in the migration of these late evolved fluids rich in F, LILE, and HFSE.
\end{abstract}

Keywords: late metasomatic replacement events, extreme F activities, LILE and HFSE enrichment, sokolovaite, fluorine analogue of nanpingite, Ángel pegmatite, Guacha Corral shear zone, Argentina

§Corresponding author e-mail address: mdemartis@exa.unrc.edu.ar 


\section{INTRODUCTION}

LCT-type pegmatites can reach extremely high degrees of fractionation, and they form from granitic melts by extensive geochemical fractionation from an initially enriched granitic magma. This extreme fractionation leads to a strong enrichment in volatile components, such as $\mathrm{H}_{2} \mathrm{O}, \mathrm{P}, \mathrm{F}$, and $\mathrm{B}$, as well as LILE ( $\mathrm{Li}, \mathrm{Cs}$, and $\mathrm{Rb}$ ) and HFSE (Nb, Ta, Sn) during primary stages of the pegmatite's history. Moreover, replacement units formed during the late stages of the pegmatite evolution can play an even more important role in the concentration (or re-concentration) of these elements, making LCT pegmatites attractive targets for rare element exploration. In some cases, mild rare-element concentrations in a barren (but fertile) pegmatite can be significantly increased up to economic amounts via late-stage replacements (Kontak 2006, Van Lichtervelde et al. 2007).

The Comechingones pegmatitic field, in central Argentina (Fig. 1), is mainly constituted of barren and beryl-type pegmatites that display low to intermediate degrees of fractionation (Demartis 2010, Demartis et al. 2012). These pegmatites have been explored for $U$ minerals and exploited for beryl. Although in general the fractionation degree is rather low, highly evolved units of metasomatic origin occur in some of the pegmatites. Here we present a textural, mineralogical, and geochemical study of one of these highly fractionated units belonging to the Ángel pegmatite, Comechingones field, which has undergone late metasomatic replacements, attaining unusual concentrations of rare alkalis, volatiles, and high field strength elements. We discuss the origin of the metasomatic fluids and suggest that the extreme $\mathrm{F}$ activities of the metasomatic fluids responsible for the replacement events played an important role in the transport and precipitation of LILE and HFSE.

\section{Geological Setting}

The Comechingones Pegmatite Field (CPF) is located in the southeastern part of the Pampean Pegmatitic Province (Galliski 1994), in the southern Sierras de Córdoba, central Argentina (Fig. 1a). The Sierras de Córdoba comprise a series of mountain ranges trending approximately $\mathrm{N}-\mathrm{S}$, which consist of pre-Andean basement blocks that were uplifted by Tertiary reverse faults. They are mostly composed of metasedimentary and igneous rocks of Precambrian to Devonian age, locally covered by sedimentary and volcanosedimentary sequences mainly of Cretaceous ages.

The basement of the Sierras de Córdoba is made up of polymetamorphic rocks. The highest metamorphic conditions belong to the upper amphibolite to granulite facies $\left(750{ }^{\circ} \mathrm{C}\right.$ and 650 to $\left.700 \mathrm{MPa}\right)$. These conditions were reached during the Pampean orogeny, in the Early
Cambrian $\left(522 \pm 8 \mathrm{Ma}\right.$ and $534 \pm 7 \mathrm{Ma},{ }^{206} \mathrm{~Pb} /{ }^{238} \mathrm{U}$ and ${ }^{208} \mathrm{~Pb} /{ }^{232} \mathrm{Th}$, respectively, analyzed by SHRIMP of monazite from garnet-rich migmatites; Rapela et al. 1998). During this event, peraluminous S-type granites and migmatites with stromatitic and nebulitic structures were produced by partial melting of metasedimentary protoliths (Otamendi et al. 2004, Fagiano 2007). Structures such as gneissic and stromatic foliation, as well as NNW-SSE-trending folds, were generated during this event (Otamendi et al. 2004).

Shearing events of the Famatinian orogeny, ranging in age from Early Ordovician to Late Devonian (480 to 365 Ma; Sims et al. 1998, Whitmeyer \& Simpson 2003, Steenken et al. 2010), reworked previous metamorphic fabrics, especially along several major shear zones of the Sierras de Córdoba. Among these, the Guacha Corral Shear Zone (GCSZ, Fig. 1b) is the largest and most complex in the Sierras de Córdoba (Martino 2003, Whitmeyer \& Simpson 2003, Otamendi et al. 2004, Fagiano 2007). It is a $\sim 120 \mathrm{~km}$ long by $20 \mathrm{~km}$ wide shear belt that crops out in the Sierra de Comechingones (one of the ranges that form the Sierras de Córdoba), with a $\mathrm{N}-\mathrm{S}$ trend, eastward dip, and moderate dipping angle. The main GCSZ deformation took place under ductile, medium- to high-amphibolite facies conditions, represented by biotite- and sillimanite-bearing mylonitic rocks (Fagiano 2007). These rocks are characterized by a fine-grained matrix composed of recrystallized biotite + quartz + K-feldspar + sillimanite, defining a mylonitic foliation that wraps around porphyroclasts of garnet and quartz + K-feldspar aggregates $0.2-2.0 \mathrm{~mm}$ in diameter. Syntectonic granites and pegmatites intruded along the GCSZ domain (Demartis et al. 2011).

Large, post-kinematic granite batholiths, such as the Cerro Âspero and Achala batholiths (Fig. 1b), intruded the GCSZ. They have discordant contacts with the country rocks and produce locally developed discontinuous thermal aureoles in mylonites of the GCSZ, evidencing post-tectonic intrusion (Pinotti et al. 2006).

\section{The Comechingones Pegmatitic Field}

Pegmatites from the CPF have been subdivided into seven groups (Hub 1994, 1995, Demartis 2010), six of which are shown in Figure 1c. They correspond to the LCT geochemical signature, and were classified as rareelement class, beryl type, beryl-columbite-phosphate subtype pegmatites (Galliski 1994). The pegmatites are mainly hosted by mylonitized gneisses, migmatites, and minor amphibolites from the GCSZ. These pegmatites were emplaced during the main shearing event of the GCSZ, showing evidence of deformation over a wide range of conditions (Demartis et al. 2011).

Pegmatites from the CPF consist of composite pegmatitic dykes, up to $1000 \mathrm{~m}$ long and $200 \mathrm{~m}$ wide, internally made up of a large number of lens- or sheetshaped pegmatitic bodies of relatively small size (less 


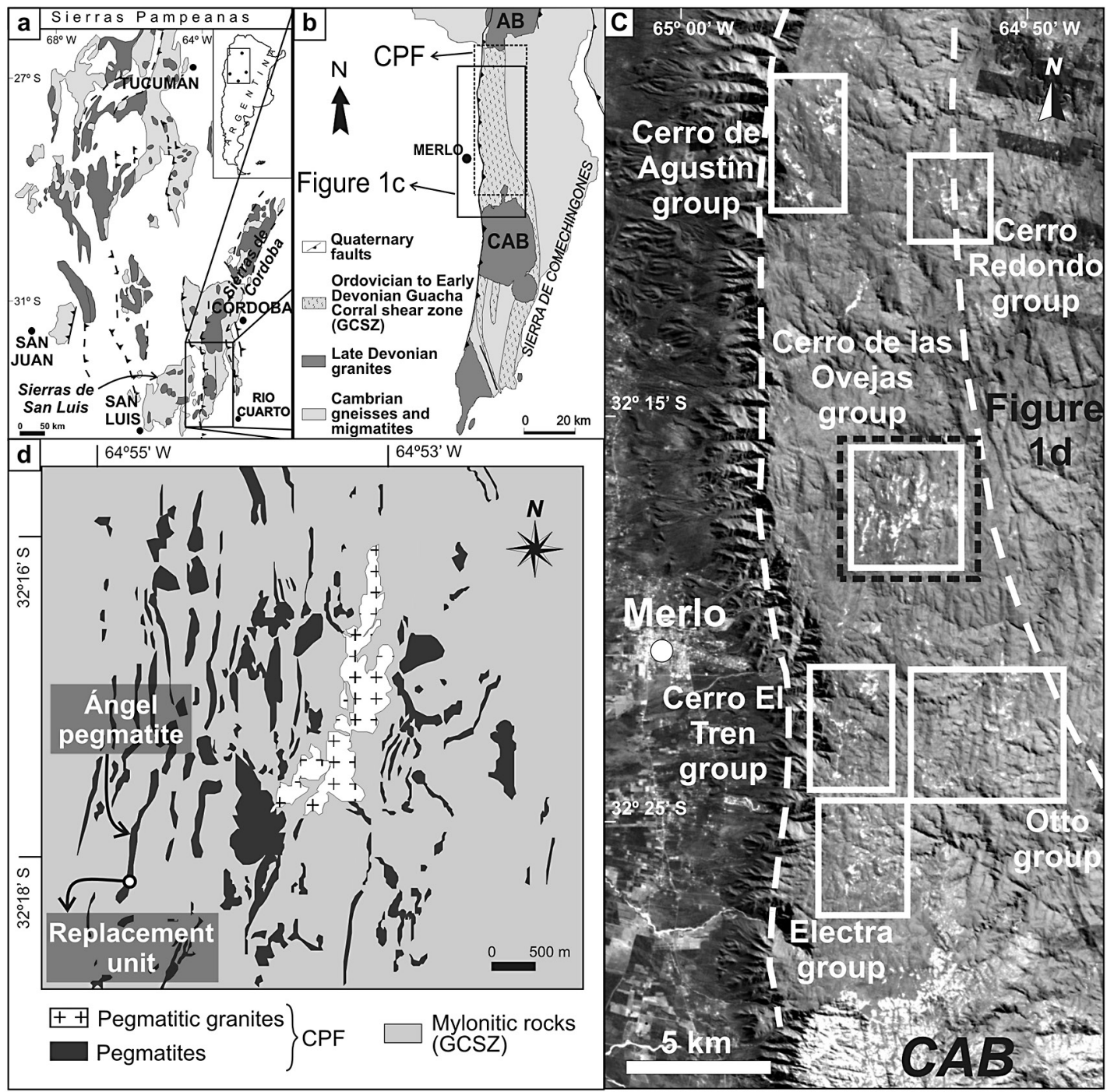

FIG. 1. (a) Geological sketch of the Sierras Pampeanas, Argentina, showing the position of the Sierras de Córdoba and Sierra de Comechingones. (b) Simplified geological map of the Sierra de Comechingones showing the extent of the Guacha Corral Shear Zone (GCSZ). The heavily lined polygon corresponds to the extension of the area amplified in Figure 1c, and the dashed rectangle corresponds to the Comechingones Pegmatitic Field (CPF). CAB: Cerro Áspero Batholith, AB: Achala Batholith. (c) CBERS satellite image of the southern part of the CPF. The black dashed rectangle indicates the area shown in Figure 1d. The different groups of pegmatites of the CPF are shown as white rectangles. The boundaries of the GCSZ are marked by white broken lines. (d) Simplified geologic map of the Cerro de las Ovejas pegmatite group, with location of the Ángel pegmatite and its replacement unit.

than $50 \mathrm{~m}$ thick and $200 \mathrm{~m}$ long, Demartis et al. 2011). The main rock-forming minerals are quartz, K-feldspar, muscovite, and plagioclase, and each pegmatite sheet tends to preserve its internal zonation. Beryllium, $\mathrm{Nb}$, and $\mathrm{U}$ mineralizations, as well as deposits of high- quality industrial minerals (feldspars, muscovite, and quartz), occur in these pegmatites.

The pegmatites are associated with bodies of pegmatitic granite, up to $2 \mathrm{~km}$ long and $500 \mathrm{~m}$ wide. These rocks are strongly foliated, and pegmatitic textures can be observed. 
Geochemical analyses of potassic feldspars from the $\mathrm{CPF}$ pegmatites reveal intermediate $\mathrm{K} / \mathrm{Rb}$ (104-351) and $\mathrm{K} / \mathrm{Cs}$ ratios (612-22.338) (Demartis et al. 2012). These values point to an intermediate fractionation degree for the Ángel pegmatite and other pegmatites of the CPF. This evidence agrees with the pegmatite classification. However, a few highly evolved latemagmatic units showing metasomatic replacements, such as that found in the Ángel pegmatite, also occur in the southern CPF.

\section{The Ángel Pegmatite AND ITS REPLACEMENT UNIT}

The Ángel pegmatite belongs to the Cerro de las Ovejas group of pegmatites (Demartis 2010), located in the central part of the CPF ( 32 $12^{\circ}$ ' S and $64^{\circ} 54.75^{\prime}$ W, Figs. 1c and d), near the village of Merlo (San Luis province). The Ángel pegmatite is particularly known because of its varied primary and secondary U mineralogy (Rigal 1938, Angelelli 1950). Like many pegmatites in the CPF, it consists of a large composite dyke, with a maximum width of $50 \mathrm{~m}$ and a length of more than $1000 \mathrm{~m}$ in outcrop, which strikes almost N-S and dips variably, from 40 to $65^{\circ}$ toward the east and west. It is internally made up of several subparallel lens- or sheet-shaped pegmatitic bodies of relatively small size (from 5 to $30 \mathrm{~m}$ thick and 200 m long) emplaced beside each other (Demartis et al. 2011). Each pegmatitic body displays an almost symmetrical zoning pattern, which generally consists of the following textural and paragenetic zones, from the contacts inward: fine- to medium-grained muscovite + quartz \pm albite grading to medium- to coarse-grained quartz + muscovite \pm microcline \pm albite, defining the wall zone. This is followed by an intermediate zone composed of a coarse- to very coarse-grained graphic microcline + quartz + muscovite \pm albite. The innermost zone consists of a quartz core with subordinate and variable amounts of very coarse-grained muscovite and microcline. Garnet, triplite-zwieselite, uraninite and its secondary products, beryl, and columbite-group minerals are the most common accessory phases, generally occurring in the intermediate zones.

The replacement unit is located in the southern part of the Ángel composite pegmatite dyke (Figs. 1d and $2 \mathrm{a})$, and it is exposed as an elliptical body about $18 \mathrm{~m}$ long and $10 \mathrm{~m}$ wide. The extension of the replacement unit could not be strictly delimited because the contacts with other pegmatitic units or mylonitic host rocks are covered by Quaternary sediments, hampering the observation of petrographic relationships among them.

\section{AnAlytical Methods}

A preliminary examination of the mineral phases and their chemical compositions was performed by petrographic and scanning-electron microscopy (SEM) using backscattered electron (BSE) observations and energy-dispersive spectroscopy (EDS). The identification of certain minerals was also supported by Raman spectroscopy, performed at the University of Barcelona. Quantitative analyses were carried out by wavelengthdispersive spectroscopy using two electron microprobes (EMPA; a CAMECA SX-50 housed at the University of Barcelona, and a JEOL JXA-8230 located at the Universidad Nacional de Córdoba). Minerals and synthetic compounds were used as standards.

Tourmaline formulae were calculated on the basis of $31(\mathrm{O}, \mathrm{F}, \mathrm{OH})$ anions, using a spreadsheet developed by Selway \& Xiong (2002). Lithium, B, and $\mathrm{H}_{2} \mathrm{O}$ were calculated by stoichiometry: $\mathrm{Li}=15-(\mathrm{T}+\mathrm{Z}+$ Y) $a p f u, \mathrm{~B}=3.00 a p f u$, and $(\mathrm{OH})+\mathrm{F}=4 a p f u . \mathrm{Fe}^{3+}$ and $\mathrm{Fe}^{2+}$ were not discriminated and $\mathrm{Fe}$ was totally reported as $\mathrm{Fe}^{2+}$.

Mica formulae were calculated on the basis of 22 $(\mathrm{O}, \mathrm{F}, \mathrm{OH})$ anions and considered the charge balance. Lithium and $\mathrm{H}_{2} \mathrm{O}$ were calculated by stoichiometry: $\mathrm{Li}$ $=6-(\mathrm{Si}+\mathrm{Al}+\mathrm{Fe}+\mathrm{Mg}+\mathrm{Mn})$ apfu for dioctahedral micas and $\mathrm{Li}=7-(\mathrm{Si}+\mathrm{Al}+\mathrm{Fe}+\mathrm{Mg}+\mathrm{Mn})$ apfu for trioctahedral micas, and $(\mathrm{OH})+\mathrm{F}=2$ anions $p f u$. $\mathrm{Fe}^{3+}$ and $\mathrm{Fe}^{2+}$ were not discriminated and $\mathrm{Fe}$ was totally reported as $\mathrm{Fe}^{+2}$.

\section{Textures and Mineral Assemblages OF THE REPLACEMENT UNIT}

A W-E section across the longest axis of the replacement unit revealed an asymmetry in the distribution of the main mineral phases (Fig. 2b). The easternmost part is dominated by prismatic albite and quartz, with subordinated muscovite flakes. A strongly foliated muscovite+albite rock, with quartz veins and ribbons and minor tourmaline, characterizes the central portion of the replacement body. At the western contact, a narrow zone less than $1 \mathrm{~m}$ thick, showing a poorly developed foliation, crops out conformably with the mylonitic foliation. This sector is composed of albite +quartz+tourmaline \pm muscovite and relics of primary muscovite. Rock samples were taken considering this zonation.

Detailed mineralogical and textural observations and electron microprobe analysis of more than 30 samples of the replacement unit of the Ángel pegmatite resulted in the recognition of three stages producing mineral assemblages, summarized in Figure 3.

The first mineral assemblage is composed of quartz, K-feldspar (microcline), albitic plagioclase, muscovite, and montebrasite. The grain size of this assemblage can attain a few centimeters in diameter. As a general rule, most of these minerals have been extensively replaced during the growth of the later units, and only some relics remain. Zircon also occurs as a relict accessory phase from the first mineral assemblage. 


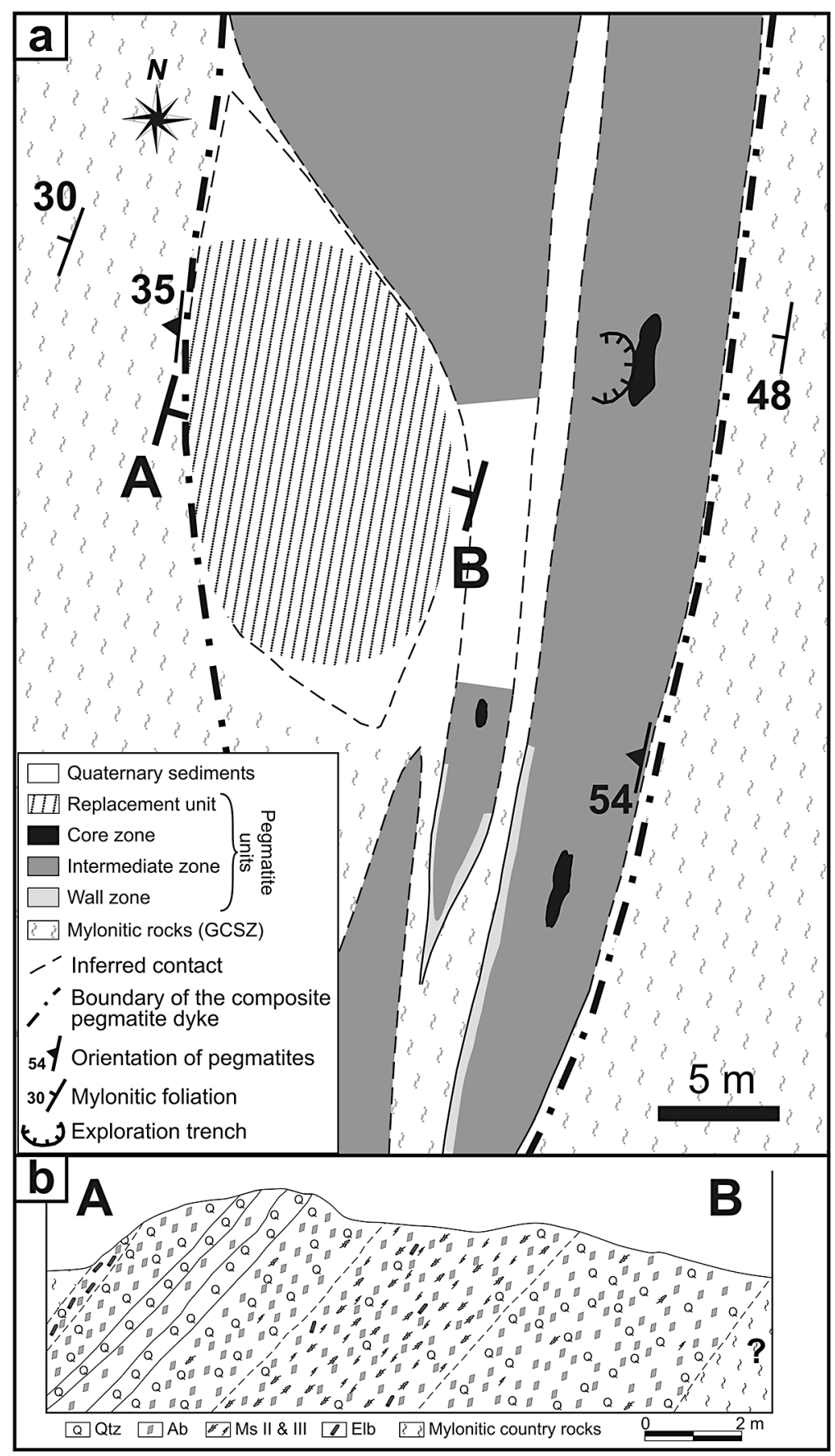

FIG. 2. (a) Geological sketch map of the area of the replacement unit, Ángel pegmatite. Several lens- or sheet-shaped pegmatitic bodies, with their own internal zonations, are also shown in order to illustrate the outcrop relationships. (b) W-E section across the longest axis of the replacement unit showing the distribution of major mineral phases (see Fig. 2a for its location). Qtz: quartz, Ab: albite, Ms II and III: muscovite II and III, Elb: elbaite. 


\begin{tabular}{|c|c|c|c|c|c|}
\hline Mineral & Formula & Stage 1 & Stage 2 & Stage 3 & Stage 4 \\
\hline Quartz I & $\mathrm{SiO}_{2}$ & & & & \\
\hline Microcline & $\mathrm{KAlSi}_{3} \mathrm{O}_{\mathrm{x}}$ & & & & \\
\hline Plagioclase & $(\mathrm{Na}, \mathrm{Ca})\left(\mathrm{Al}, \mathrm{Si}_{4} \mathrm{O}_{8}\right.$ & & & & \\
\hline Muscovite I & $\mathrm{KAl}_{2} \mathrm{AlSi}_{3} \mathrm{O}_{\mathrm{to}}(\mathrm{OH})_{2}$ & & & & \\
\hline Montebrasite & $\mathrm{LiAl}\left(\mathrm{PO}_{4}\right)(\mathrm{OH}, \mathrm{F})$ & & & & \\
\hline Zircon & $\mathrm{ZrSiO}_{4}$ & & & & \\
\hline Albite I & $\mathrm{NaAISi}_{3} \mathrm{O}_{8}$ & & & & \\
\hline Albite II (cleavelandite) & $\mathrm{NaAlSi}_{3} \mathrm{O}_{8}$ & & & & \\
\hline Muscovite II & $(\mathrm{K}, \mathbf{R b}, \mathbf{C s})(\mathrm{Al}, \mathrm{Li})_{2} \mathrm{AlSi}_{3} \mathrm{O}_{10}(\mathrm{OH}, \mathbf{F})_{2}$ & & & & \\
\hline Quartz II & $\mathrm{SiO}_{2}$ & & & & \\
\hline Elbaite I & $\mathrm{Na}(\mathrm{Li}, \mathrm{Al})_{3} \mathrm{Al}_{6}\left(\mathrm{BO}_{3}\right)_{3} \mathrm{Si}_{6} \mathrm{O}_{18}(\mathrm{OH})_{4}$ & & & & \\
\hline Topaz & $\mathrm{Al}_{2} \mathrm{SiO}_{4}(\mathrm{~F}, \mathrm{OH})_{2}$ & & & & \\
\hline Fluorapatite & $\mathrm{Ca}_{5}\left(\mathrm{PO}_{4}\right)_{3}(\mathbf{F}, \mathrm{OH}, \mathrm{Cl})$ & & & & \\
\hline Lacroixite & $\operatorname{NaAl}\left(\mathrm{PO}_{4}\right) \mathrm{F}$ & & & & \\
\hline Columbite-(Mn) & $(\mathrm{Mn}, \mathrm{Fe} \cdot)\left(\mathrm{Nb}, \mathrm{Ta}_{2}\right)_{6}$ & & - & & \\
\hline Hf-rich zircon & $(\mathrm{Zr}, \mathrm{Hf}) \mathrm{SiO}_{4}$ & & & & \\
\hline Pollucite & $\left(\mathrm{Cs}, \mathrm{Na}_{2}\right)_{2} \mathrm{Al}_{2} \mathrm{Si}_{4} \mathrm{O}_{12} \cdot\left(\mathrm{H}_{2} \mathrm{O}\right)$ & & & & \\
\hline F-analogue of muscovite (III) & $(\mathrm{K}, \mathbf{R b}, \mathbf{C s})(\mathrm{Al}, \mathbf{L i})_{2} \mathrm{AlSi}_{3} \mathrm{O}_{10}(\mathbf{F}, \mathrm{OH})_{2}$ & & & & \\
\hline Elbaite II & $\mathrm{Na}(\mathrm{Li}, \mathrm{Al})_{3} \mathrm{Al}_{6}\left(\mathrm{BO}_{3}\right)_{3} \mathrm{Si}_{6} \mathrm{O}_{18}(\mathrm{OH})_{4}$ & & & & \\
\hline U-rich hydroxykenomicrolite & $(\mathrm{U}, \mathrm{Ca})_{2}(\mathrm{Ta}, \mathrm{Nb})_{2} \mathrm{O}_{6}(\mathrm{OH})$ & & & & \\
\hline Bismuth & $\mathrm{Bi}$ & & & & \\
\hline F-analogue of nanpingite & $\mathrm{Cs}(\mathrm{Al}, \mathbf{L i})_{2} \mathrm{Si}_{4} \mathrm{O}_{10}(\mathbf{F}, \mathrm{OH})_{2}$ & & & & \\
\hline Sokolovaite & $\mathrm{CsLi}_{2} \mathrm{AlSi}_{4} \mathrm{O}_{10} \mathbf{F}_{2}$ & & & & \\
\hline Chlorapatite & $\mathrm{Ca}_{5}\left(\mathrm{PO}_{4}\right)_{3} \mathrm{Cl}$ & & & & \\
\hline Other secondary phosphates & & & & & \\
\hline Kaolinite & $\mathrm{Al}_{2} \mathrm{Si}_{2} \mathrm{O}_{5}(\mathrm{OH})_{4}$ & & & & \\
\hline
\end{tabular}

FIG. 3. Schematic sequence of the mineral assemblage formation during the different paragenetic stages of the replacement unit. The line thickness represents the relative abundance of each mineral.

The second mineral assemblage replaced the first one. Microcline was largely replaced by secondary prismatic albite (albite I), and only scarce remnants of microcline were preserved. In turn, minerals belonging to stage 1 , especially muscovite and montebrasite, were replaced by a second generation of muscovite (muscovite II), which is pale violet in hand specimen. An irregular replacement was produced along cleavages, small fractures, and grain boundaries. Muscovite II is accompanied by large amounts of platy albite (cleavelandite variety, albite II), quartz, and topaz. In addition, pale-colored prismatic crystals of members of the schorl-elbaite series (elbaite I) occur scattered among the above minerals. Lacroixite and fluorapatite also occur as the products of alteration of primary montebrasite. All of these phases tend to display millimeter-sized rounded crystals, and the ensemble has a mylonitic fabric. Minor amounts of columbite-(Mn), pollucite, and Hf-rich zircon occur as small inclusions.

During the third stage, another replacement event generated a new mineral assemblage in which the micas were particularly affected. Muscovite I and II were replaced by a third generation of muscovite (muscovite III), which is characterized by a strong enrichment in $\mathrm{F}$ and Cs. At the same time, elbaite I was replaced by a second generation of elbaite (elbaite II), which is enriched in the elbaite component and relatively impov- erished in Fe. These minerals are accompanied by small amounts of anhedral crystals of the microlite group, of some hundreds of microns in size and with a strong enrichment in U. Bismuth is commonly found as a late alteration of some of the above minerals. Fine-grained (less than $50 \mu \mathrm{m}$ ) sokolovaite and an F-analogue of nanpingite replace the preexisting micas, particularly muscovite II, at the end of this stage.

Finally, supergene processes led to the replacement of many of the above minerals. Feldspars can be pseudomorphosed by kaolinite, whereas montebrasite was replaced by an assemblage of chlorapatite and diverse fine-grained secondary phosphates. These occur as delicate euhedral crystals infilling geodic porosity and as patchy textured crystals in the interstices of older crystal boundaries. These associations are dominated by minerals extremely enriched in $\mathrm{Zr}, \mathrm{Hf}, \mathrm{Ca}, \mathrm{Sr}, \mathrm{Mn}$, and $\mathrm{Al}$.

As stated above, the intense deformation that took place during the emplacement and consolidation of the pegmatites from the CPF generated strongly foliated fabrics with typical mylonitic textures (Demartis et al. 2011). Hence, the replacement unit of the Ángel pegmatite is texturally porphyroclastic, where the large, coarse-grained crystals of assemblage 1 behaved as competent porphyroclasts (Fig. 4a). 


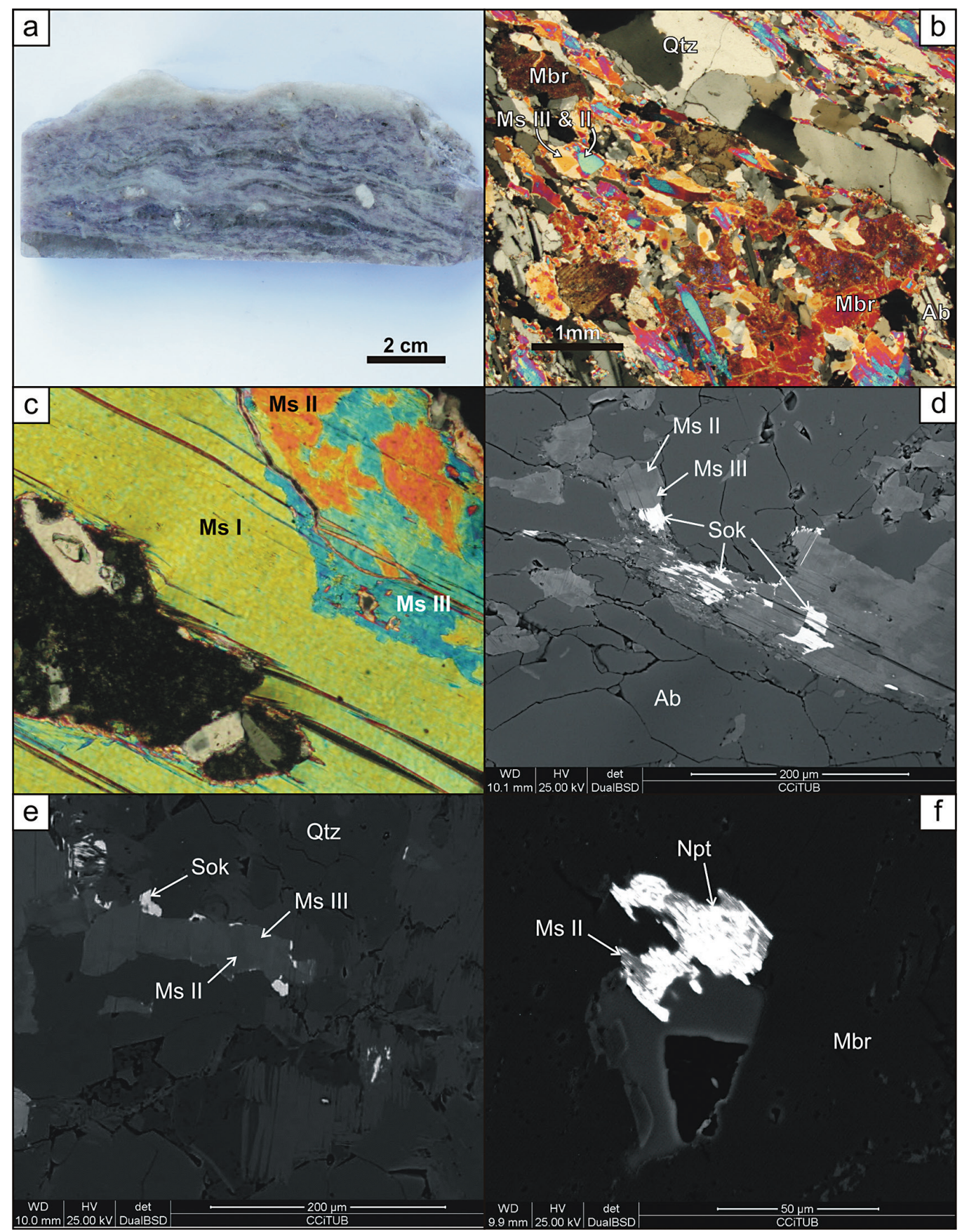

FIG. 4. (a) Cut hand specimen of a strongly foliated, mylonitic-textured rock from the central portion of the replacement unit. Light-colored porphyroclasts are generally montebrasite, albite, or muscovite; the purple zones are mostly composed of muscovite II \& III + albite. (b) Cross-polarized photomicrographs of the replacement unit, showing muscovites II and III (Ms II and III) and albite $(\mathrm{Ab})$ intergrowths replacing a coarse-grained, polysynthetically twinned montebrasite porphyroclast. (c) Cross-polarized photomicrographs showing a large relict muscovite (Ms I) crystal partially replaced by muscovite II and III (Ms II and Ms III) along its boundary (upper right). (d) and (e) BSE images of muscovite II and III with patchy intergrowths of sokolovaite (Sok) altering both of them. (f) BSE image of the F-analogue of nanpingite (Npt) replacing muscovite II (Ms II), surrounded by a large montebrasite (Mbr) crystal. 


\section{Mineralogy And Mineral Chemistry}

\section{Feldspars}

Albite is very abundant. It occurs both as coarsegrained porphyroclasts (up to several centimeters in diameter) with variable deformation intensity and as medium- to fine-grained tabular crystals in the matrix ( $\sim 1 \mathrm{~mm}$ long). Albite from the matrix is the result of subgrain recrystallization during deformation of large crystals. It also crystallized directly from metasomatic fluids, occurring more frequently as short prismatic crystals and bladed platy crystals with radial habits. Microprobe analyses show that all compositions have more than $99 \%$ of the Ab component, with virtually no chemical differences between types of occurrence. As stated above, $\mathrm{K}$-feldspars were only observed as relict large crystals, reaching several centimeters in diameter, which have been almost completely replaced by later assemblages. Structurally, K-feldspar crystals from intermediate zones of the Angel pegmatite and other pegmatites of the $\mathrm{CPF}$ generally correspond to low microcline, with structures almost completely ordered $\left(\mathrm{t}_{1} \mathrm{O}\right.$ values ranging between 0.947 and 0.997 ; Demartis 2010).

\section{Montebrasite-amblygonite}

Montebrasite occurs mostly in the central part of the replacement unit as centimeter-sized crystals that behaved as porphyroclasts during deformation. These crystals are interpreted to be relics of primary crystallization in the intermediate zones. They are typically round to elliptical $\sigma$ - and $\theta$-type grains with polysynthetic twinning (Figs. 4a and b). They are frequently replaced by albite and muscovite II and III of variable grain size, especially along grain boundaries. Alteration processes also pervasively affected the inner parts of the montebrasite crystals, resulting in the replacement of montebrasite by secondary phosphates, such as lacroixite and fluorapatite. Other secondary, probably supergene, phosphate minerals also occur in the latestage alteration (see below).

Chemical analysis performed on unaltered parts of montebrasite porphyroclasts show compositions corresponding to a F-rich montebrasite, with uniform $\mathrm{F}$ contents that can attain 0.44 apfu (Table 1). Major components are also quite uniform. Lithium substitution by $\mathrm{Na}, \mathrm{K}$, and $\mathrm{Ca}$, as well as $\mathrm{Al}$ substitution by $\mathrm{Fe}, \mathrm{Mn}$, and $\mathrm{Mg}$, are negligible.

\section{Micas}

Three types of micas have been recognized in the replacement unit of the Ángel pegmatite: (1) large crystals of muscovite from the primary assemblage (muscovite I); (2) two generations of muscovite of metasomatic origin (muscovite II and III); and (3) sokolovaite (Cs-analogue of polylithionite) and an F-analogue of nanpingite generated by late Cs-enrichment of muscovite grains.

Muscovite I commonly occurs as large crystals, $\sim 3 \mathrm{~cm}$ in diameter, with folded sheets and mica-fish textures, and represents part of the relict primary mineral assemblage. Boundaries are commonly altered and replaced by two generations of muscovite (see below). Microprobe analyses obtained from the relict large muscovite I crystals yielded compositions close to the ideal formula, with only minor amounts of $\mathrm{Rb}$ (up to $0.02 a p f u$ ) and Cs (less than $0.01 a p f u$ ). Fluorine contents are also low (up to $0.33 a p f u$, Table 2). The paragonite component is also low, with $\mathrm{Na}$ content lower than 0.09 apfu. Hence, the interlayer cation site is dominated by $\mathrm{K}$.

Micas represent the volumetrically most important component formed during the metasomatic replacement. They are distributed throughout the entire unit but are more abundant in its central part (Fig. 2b). They occur as purple-colored crystals, generally less than $1 \mathrm{~mm}$ long, showing a preferred orientation that defines the mylonitic foliation of the rock. Finegrained muscovite II flakes replace albite grains from the matrix and coarse-grained montebrasite (Fig. 4b). Relic muscovite I crystals are replaced along grain boundaries by a 100-300 $\mu \mathrm{m}$ thick rim of muscovite II (Fig. 4c). Muscovite II is, in turn, irregularly replaced by muscovite III (Figs. 4c-e).

Muscovite II is slightly enriched in Li (up to 0.28 $a p f u$ ), Cs (up to $0.03 a p f u$ ), and Rb (up to $0.06 a p f u$ ) when compared with muscovite I (Table 2). In contrast, $\mathrm{K}$ and $\mathrm{Na}$ (up to $0.06 \mathrm{apfu}$ ) are slightly depleted. Moreover, F may occupy most of the additional anion site (up to $1.56 \mathrm{apfu}$ ).

Muscovite III is notably enriched in Li (up to 0.37 $a p f u$ ), Cs (up to $0.07 a p f u$ ), and Rb (up to $0.06 a p f u$ ) when compared with the previous muscovite generations (Table 2). Fluorine is also higher, and may totally fill the site (up to $1.94 \mathrm{apfu}$ ); this mica therefore corresponds to an F-analogue of muscovite.

Sokolovaite is not ubiquitously distributed. It occurs replacing some muscovite grains along their rims and cleavages and, less frequently, their inner parts (Figs. $4 \mathrm{~d}$ and e). Sokolovaite identification was confirmed by EMPA analyses (Table 2, Fig. 5) along with the different generations of muscovite. The triangular $\mathrm{K}-\mathrm{Cs}-\mathrm{Rb}$ diagram of Figure 5a reflects a Cs enrichment trend from muscovite I to sokolovaite and the $\mathrm{F}$-analogue of nanpingite. Cesium contents as high as 0.90 apfu were observed in sokolovaite, only slightly lower than the Cs values obtained for sokolovaite from the type locality in northern Tajikistan (0.94 apfu; Pautov et al. 2006). Potter et al. (2009) reported lower Cs values (up to $0.73 \mathrm{Cs} a p f u$ ) in the main body of the Moblan pegmatite cluster in Quebec, Canada, that are accom- 
TABLE 1. CHEMICAL COMPOSITION OF PRIMARY (MONTEBRASITE) AND SECONDARY (LACROIXITE) PHOSPHATES FROM THE REPLACEMENT UNIT OF THE ÁNGEL PEGMATITE

\begin{tabular}{|c|c|c|c|c|c|c|}
\hline & \multicolumn{3}{|c|}{$\begin{array}{c}\text { montebrasite } \\
\quad(n=15)\end{array}$} & \multicolumn{3}{|c|}{$\begin{array}{l}\text { lacroixite } \\
(n=3)\end{array}$} \\
\hline & Min & Max & $\begin{array}{l}\text { Average } \\
\text { (Std. Dev.) }\end{array}$ & Min & Max & $\begin{array}{l}\text { Average } \\
\text { (Std. Dev.) }\end{array}$ \\
\hline $\mathrm{P}_{2} \mathrm{O}_{5}$ wt. $\%$ & 46.30 & 49.40 & $48.39(0.86)$ & 44.08 & 45.27 & $44.65(0.60)$ \\
\hline $\mathrm{SiO}_{2}$ & b.d.I. & 0.20 & $0.05(0.06)$ & b.d.l. & 0.01 & $0.01(0.01)$ \\
\hline $\mathrm{SO}_{3}$ & b.d.l. & 0.09 & $0.02(0.03)$ & n.d. & n.d. & n.d. \\
\hline $\mathrm{Al}_{2} \mathrm{O}_{3}$ & 33.34 & 36.05 & $34.35(0.75)$ & 32.71 & 33.52 & $33.17(0.41)$ \\
\hline $\mathrm{FeO}$ & b.d.l. & 0.12 & $0.05(0.04)$ & b.d.l. & b.d.l. & $0.00(0.00)$ \\
\hline $\mathrm{MnO}$ & b.d.l. & 0.13 & $0.03(0.04)$ & b.d.l. & 0.17 & $0.07(0.09)$ \\
\hline $\mathrm{MgO}$ & b.d.l. & 0.03 & $0.01(0.01)$ & n.d. & n.d. & n.d. \\
\hline $\mathrm{CaO}$ & b.d.l. & 2.34 & $0.19(0.60)$ & b.d.l. & 0.05 & $0.02(0.03)$ \\
\hline $\mathrm{SrO}$ & b.d.l. & 0.22 & $0.04(0.08)$ & n.d. & n.d. & n.d. \\
\hline $\mathrm{BaO}$ & b.d.l. & 0.17 & $0.02(0.06)$ & n.d. & n.d. & n.d. \\
\hline $\mathrm{Na}_{2} \mathrm{O}$ & b.d.l. & 0.12 & $0.02(0.03)$ & 12.51 & 13.38 & $12.88(0.45)$ \\
\hline $\mathrm{K}_{2} \mathrm{O}$ & b.d.l. & 0.04 & $0.01(0.01)$ & b.d.l. & 0.02 & $0.01(0.01)$ \\
\hline $\mathrm{F}$ & 2.71 & 5.69 & $4.99(0.90)$ & 9.09 & 9.49 & $9.26(0.20)$ \\
\hline $\mathrm{Cl}$ & b.d.l. & 0.04 & $0.01(0.01)$ & n.d. & n.d. & n.d. \\
\hline $\mathrm{Li}_{2} \mathrm{O}^{*}$ & 9.06 & 10.39 & $10.12(0.33)$ & 2.82 & 3.48 & $3.18(0.33)$ \\
\hline $\mathrm{H}_{2} \mathrm{O}^{*}$ & 3.35 & 4.77 & $3.77(0.44)$ & 1.23 & 1.35 & $1.27(0.06)$ \\
\hline$-\mathrm{O}=\mathrm{F}$ & -2.40 & -1.14 & $-2.10(0.38)$ & -3.83 & -4.00 & $-3.90(-0.09)$ \\
\hline$-\mathrm{O}=\mathrm{Cl}$ & -0.01 & 0.00 & $0.00(0.00)$ & - & - & - \\
\hline Total & 98.92 & 101.35 & $99.93(0.77)$ & 100.38 & 100.81 & $100.61(0.21)$ \\
\hline P apfu & 1.00 & 1.00 & $1.00(0.00)$ & 1.00 & 1.00 & $1.00(0.00)$ \\
\hline $\mathrm{Si}$ & 0.00 & 0.00 & $0.00(0.00)$ & 0.00 & 0.00 & $0.00(0.00)$ \\
\hline$S$ & 0.00 & 0.00 & $0.00(0.00)$ & - & - & - \\
\hline $\mathrm{Al}$ & 0.95 & 1.08 & $0.99(0.04)$ & 1.01 & 1.06 & $1.03(0.03)$ \\
\hline $\mathrm{Fe}$ & 0.00 & 0.00 & $0.00(0.00)$ & 0.00 & 0.00 & $0.00(0.00)$ \\
\hline $\mathrm{Mn}$ & 0.00 & 0.00 & $0.00(0.00)$ & 0.00 & 0.00 & $0.00(0.00)$ \\
\hline $\mathrm{Mg}$ & 0.00 & 0.00 & $0.00(0.00)$ & - & - & - \\
\hline $\mathrm{Li}$ & 0.93 & 1.00 & $0.99(0.02)$ & 0.30 & 0.37 & $0.34(0.03)$ \\
\hline $\mathrm{Na}$ & 0.00 & 0.01 & $0.00(0.00)$ & 0.63 & 0.70 & $0.66(0.03)$ \\
\hline $\mathrm{K}$ & 0.00 & 0.00 & $0.00(0.00)$ & 0.00 & 0.00 & $0.00(0.00)$ \\
\hline $\mathrm{F}$ & 0.21 & 0.44 & $0.39(0.07)$ & 0.76 & 0.78 & $0.78(0.01)$ \\
\hline $\mathrm{Cl}$ & 0.00 & 0.00 & $0.00(0.00)$ & - & - & - \\
\hline $\mathrm{OH}$ & 0.56 & 0.79 & $0.61(0.07)$ & 0.22 & 0.24 & $0.22(0.01)$ \\
\hline $\mathrm{Na} /(\mathrm{Na}+\mathrm{Li})$ & 0.00 & 0.01 & $0.00(0.00)$ & 0.63 & 0.70 & $0.66(0.03)$ \\
\hline
\end{tabular}

*Determined by stoichiometry. Formula contents based on one phosphorous, assuming 1( $\mathrm{Li}$ $+\mathrm{Na}+\mathrm{K}+\mathrm{Ca}+\mathrm{Sr}+\mathrm{Ba})$ and $1(\mathrm{OH}+\mathrm{F}+\mathrm{Cl})$ per formula unit. n.d. = not determined. b.d.I. $=$ below detection limit

panied by high $\mathrm{Rb}$ (up to $0.22 \mathrm{Rb} a p f u$ ). By contrast, the $\mathrm{Rb}$ content does not achieve more than $0.03 \mathrm{apfu}$ in the sokolovaite crystals from Comechingones. Tetrahedrally coordinated $\mathrm{Al}$ may be as low as $0.23 \mathrm{apfu}$. Fluorine contents are very close to 2 apfu in all of our sokolovaite analyses, with negligible $\mathrm{OH}$ contents.

The F-analogue of nanpingite is scarce and occurs as a replacement product of the above muscovite generations. Similar textural relationships between muscovite and nanpingite were found in evolved pegmatites from Angola (Gonçalves et al. 2009). Unfortunately, the textural relationships between this mica and sokolovaite could not be observed, as the grains are not in mutual contact. The chemical composition of the F-analogue of nanpingite is more evolved than the composition reported for the type locality. The Cs content may almost fill the interlayer site, attaining 0.94 apfu (Table 2, Fig. 5a and b), higher than the reported value from China (0.88 apfu; Ni 1996). The Li contents may attain $0.47 a p f u$ at the octahedral site in the case of the Comechingones nanpingite, whereas these values are not higher than 0.15 apfu in the Chinese material. 
Moreover, the site for additional anions is mainly occupied by $\mathrm{F}$ in the Comechingones nanpingite (Table 2) and, hence, these compositions could probably correspond to a new endmember of the mica group (Fig. 5b), an F-analogue of nanpingite.

The compositions of the micas from the replacement units of the Ángel pegmatite record an evolution trend characterized by simultaneous and progressive enrichment of $\mathrm{F}$ and $\mathrm{Cs}$, reaching exceptionally high contents for both elements (Figs. 5a and b).

\section{Tourmaline}

Tourmaline occurs locally in the western part of the replacement unit, in tourmaline-rich layers parallel to the mylonitic foliation orientation, next to the contact with the mylonitic host rocks. These layers are composed of fine-grained, short, prismatic tourmaline crystals mostly associated with F-rich muscovite. The tourmaline crystals are black in hand sample and show pleochroism in shades of blue under plane polarized

TABLE 2. REPRESENTATIVE ANALYSES OF MICAS FROM THE REPLACEMENT UNIT OF THE ÁNGEL PEGMATITE

\begin{tabular}{|c|c|c|c|c|c|c|c|c|c|c|c|}
\hline & \multicolumn{2}{|c|}{ Muscovite I } & \multicolumn{3}{|c|}{ Muscovite II } & \multicolumn{6}{|c|}{ Muscovite III } \\
\hline & e3 5-32 & e3 5-33 & w1a9-52 & 01 5-10 & 01 5-11 & $015-8$ & $015-9$ & $02 x-28$ & e3 5 -31 & w1a9-60 & $02 x-27$ \\
\hline $\mathrm{SiO}_{2}$ wt. $\%$ & 47.16 & 47.25 & 50.05 & 54.25 & 53.09 & 55.90 & 55.43 & 54.45 & 50.22 & 54.99 & 54.35 \\
\hline $\mathrm{Al}_{2} \mathrm{O}_{3}$ & 35.72 & 35.92 & 28.95 & 26.68 & 28.64 & 22.86 & 23.62 & 24.80 & 27.96 & 20.90 & 27.04 \\
\hline $\mathrm{FeO}$ & 1.50 & 1.33 & 2.12 & 0.14 & 0.16 & 0.12 & 0.06 & 0.27 & 2.53 & 2.07 & 0.15 \\
\hline $\mathrm{MnO}$ & 0.11 & 0.16 & 0.79 & 0.32 & 0.40 & 0.35 & 0.43 & 0.39 & 0.44 & 1.63 & 0.31 \\
\hline $\mathrm{MgO}$ & 0.02 & 0.00 & 0.29 & 0.00 & 0.00 & 0.00 & 0.00 & 0.00 & 0.03 & 0.40 & 0.00 \\
\hline $\mathrm{Li}_{2} \mathrm{O}^{*}$ & 0.11 & 0.09 & 0.43 & 1.04 & 0.81 & 1.38 & 1.32 & 1.15 & 0.63 & 1.13 & 0.99 \\
\hline $\mathrm{CaO}$ & 0.00 & 0.00 & 0.00 & 0.00 & 0.00 & 0.00 & 0.00 & 0.00 & 0.00 & 0.00 & 0.00 \\
\hline $\mathrm{Na}_{2} \mathrm{O}$ & 0.68 & 0.67 & 0.25 & 0.39 & 0.47 & 0.27 & 0.32 & 0.35 & 0.12 & 0.20 & 0.37 \\
\hline $\mathrm{K}_{2} \mathrm{O}$ & 10.21 & 10.01 & 9.64 & 10.09 & 9.72 & 10.00 & 10.09 & 9.60 & 9.86 & 10.02 & 9.60 \\
\hline $\mathrm{Rb}_{2} \mathrm{O}$ & 0.30 & 0.45 & 0.91 & 1.29 & 1.23 & 1.37 & 1.40 & 1.37 & 1.10 & 0.80 & 1.24 \\
\hline $\mathrm{Cs}_{2} \mathrm{O}$ & 0.07 & 0.12 & 0.87 & 0.15 & 0.12 & 1.19 & 1.15 & 1.22 & 1.24 & 2.28 & 1.18 \\
\hline $\mathrm{F}$ & 1.55 & 1.61 & 4.26 & 7.44 & 6.38 & 9.07 & 8.33 & 8.27 & 5.22 & 8.20 & 6.71 \\
\hline $\mathrm{H}_{2} \mathrm{O}^{*}$ & 3.81 & 3.79 & 2.42 & 0.98 & 1.50 & 0.14 & 0.50 & 0.52 & 1.93 & 0.50 & 1.35 \\
\hline Total & 101.24 & 101.40 & 100.98 & 102.77 & 102.52 & 102.64 & 102.65 & 102.38 & 101.28 & 103.12 & 103.28 \\
\hline $\mathrm{O}=\mathrm{F}$ & 0.65 & 0.68 & 1.79 & 3.13 & 2.69 & 3.82 & 3.51 & 3.48 & 2.20 & 3.45 & 2.83 \\
\hline Total & 100.59 & 100.72 & 99.19 & 99.64 & 99.83 & 98.83 & 99.14 & 98.91 & 99.08 & 99.67 & 100.46 \\
\hline Si apfu & 3.11 & 3.11 & 3.38 & 3.61 & 3.52 & 3.78 & 3.74 & 3.68 & 3.42 & 3.75 & 3.60 \\
\hline${ }^{\mathrm{IV}} \mathrm{Al}$ & 0.89 & 0.89 & 0.62 & 0.39 & 0.48 & 0.22 & 0.26 & 0.32 & 0.58 & 0.25 & 0.40 \\
\hline $\mathrm{T}$ site & 4.00 & 4.00 & 4.00 & 4.00 & 4.00 & 4.00 & 4.00 & 4.00 & 4.00 & 4.00 & 4.00 \\
\hline $\mathrm{VI}^{\mathrm{Al}}$ & 1.88 & 1.89 & 1.69 & 1.70 & 1.75 & 1.60 & 1.61 & 1.65 & 1.66 & 1.44 & 1.71 \\
\hline $\mathrm{Fe}$ & 0.08 & 0.07 & 0.12 & 0.01 & 0.01 & 0.01 & 0.00 & 0.02 & 0.14 & 0.12 & 0.01 \\
\hline $\mathrm{Mn}$ & 0.01 & 0.01 & 0.05 & 0.02 & 0.02 & 0.02 & 0.02 & 0.02 & 0.03 & 0.09 & 0.02 \\
\hline $\mathrm{Mg}$ & 0.00 & 0.00 & 0.03 & 0.00 & 0.00 & 0.00 & 0.00 & 0.00 & 0.00 & 0.04 & 0.00 \\
\hline $\mathrm{Li}$ & 0.03 & 0.02 & 0.12 & 0.28 & 0.22 & 0.37 & 0.36 & 0.31 & 0.17 & 0.31 & 0.26 \\
\hline O site & 2.00 & 2.00 & 2.00 & 2.00 & 2.00 & 2.00 & 2.00 & 2.00 & 2.00 & 2.00 & 2.00 \\
\hline $\mathrm{Ca}$ & 0.00 & 0.00 & 0.00 & 0.00 & 0.00 & 0.00 & 0.00 & 0.00 & 0.00 & 0.00 & 0.00 \\
\hline $\mathrm{Na}$ & 0.09 & 0.09 & 0.03 & 0.05 & 0.06 & 0.04 & 0.04 & 0.05 & 0.02 & 0.03 & 0.05 \\
\hline K & 0.86 & 0.84 & 0.83 & 0.86 & 0.82 & 0.86 & 0.87 & 0.83 & 0.86 & 0.87 & 0.81 \\
\hline $\mathrm{Rb}$ & 0.01 & 0.02 & 0.04 & 0.06 & 0.05 & 0.06 & 0.06 & 0.06 & 0.05 & 0.04 & 0.05 \\
\hline Cs & 0.00 & 0.00 & 0.03 & 0.00 & 0.00 & 0.03 & 0.03 & 0.04 & 0.04 & 0.07 & 0.03 \\
\hline Interlayer & 0.96 & 0.95 & 0.93 & 0.97 & 0.94 & 0.99 & 1.00 & 0.97 & 0.96 & 1.00 & 0.94 \\
\hline $\mathrm{F}$ & 0.32 & 0.33 & 0.91 & 1.56 & 1.34 & 1.94 & 1.78 & 1.77 & 1.12 & 1.77 & 1.41 \\
\hline $\mathrm{OH}$ calc & 1.68 & 1.67 & 1.09 & 0.44 & 0.66 & 0.06 & 0.22 & 0.23 & 0.88 & 0.23 & 0.59 \\
\hline Anions & 2.00 & 2.00 & 2.00 & 2.00 & 2.00 & 2.00 & 2.00 & 2.00 & 2.00 & 2.00 & 2.00 \\
\hline
\end{tabular}

* Determined by stoichiometry assuming $\mathrm{Si}+\mathrm{Al}+\mathrm{Fe}+\mathrm{Mg}+\mathrm{Mn}+\mathrm{Li}=6$ apfu in dioctahedral micas (muscovite I, II, and III; and F-analogue of nanpingite) and $\mathrm{Si}+\mathrm{Al}+\mathrm{Fe}+\mathrm{Mg}+\mathrm{Mn}+\mathrm{Li}=7$ apfu in trioctahedral micas (sokolovaite). $\mathrm{H}_{2} \mathrm{O}$ proportions were also calculated by stoichiometry assuming $(\mathrm{OH}+\mathrm{F})=2$ anions per formula unit. 
TABLE 2 (CONTINUED). REPRESENTATIVE ANALYSES OF MICAS FROM THE REPLACEMENT UNIT OF THE ÁNGEL PEGMATITE

\begin{tabular}{|c|c|c|c|c|}
\hline & \multicolumn{2}{|c|}{ sokolovaite } & \multicolumn{2}{|c|}{$\begin{array}{c}\text { F-analogue of } \\
\text { nanpingite }\end{array}$} \\
\hline & w1a9-48 & w1a9-62 & 01 5-13 & w1a9-56 \\
\hline $\mathrm{SiO}_{2}$ wt. $\%$ & 45.70 & 48.44 & 51.11 & 48.58 \\
\hline $\mathrm{Al}_{2} \mathrm{O}_{3}$ & 14.11 & 13.93 & 19.09 & 15.26 \\
\hline $\mathrm{FeO}$ & 1.87 & 0.79 & 0.08 & 0.76 \\
\hline $\mathrm{MnO}$ & 1.06 & 0.66 & 0.35 & 0.57 \\
\hline $\mathrm{MgO}$ & 0.29 & 0.11 & 0.00 & 0.18 \\
\hline $\mathrm{Li}_{2} \mathrm{O}^{*}$ & 5.57 & 5.91 & 1.31 & 1.44 \\
\hline $\mathrm{CaO}$ & 0.01 & 0.01 & 0.02 & 0.00 \\
\hline $\mathrm{Na}_{2} \mathrm{O}$ & 0.07 & 0.05 & 0.51 & 0.04 \\
\hline $\mathrm{K}_{2} \mathrm{O}$ & 0.94 & 2.37 & 1.71 & 0.72 \\
\hline $\mathrm{Rb}_{2} \mathrm{O}$ & 0.59 & 0.46 & 0.52 & 0.47 \\
\hline $\mathrm{Cs}_{2} \mathrm{O}$ & 26.38 & 21.69 & 21.22 & 27.22 \\
\hline $\mathrm{F}$ & 7.35 & 7.94 & 7.16 & 7.06 \\
\hline $\mathrm{H}_{2} \mathrm{O}^{*}$ & 0.27 & 0.09 & 0.57 & 0.34 \\
\hline Total & 104.21 & 102.45 & 103.65 & 102.64 \\
\hline $\mathrm{O}=\mathrm{F}$ & 3.09 & 3.34 & 3.01 & 2.97 \\
\hline Total & 101.12 & 99.11 & 100.64 & 99.66 \\
\hline Si apfu & 3.65 & 3.77 & 3.87 & 3.95 \\
\hline${ }^{\mathrm{IV}} \mathrm{Al}$ & 0.35 & 0.23 & 0.13 & 0.05 \\
\hline T site & 4.00 & 4.00 & 4.00 & 4.00 \\
\hline${ }^{\mathrm{VI}} \mathrm{Al}$ & 0.98 & 1.04 & 1.57 & 1.42 \\
\hline $\mathrm{Fe}$ & 0.12 & 0.05 & 0.01 & 0.05 \\
\hline $\mathrm{Mn}$ & 0.07 & 0.04 & 0.02 & 0.04 \\
\hline $\mathrm{Mg}$ & 0.03 & 0.01 & 0.00 & 0.02 \\
\hline $\mathrm{Li}$ & 1.79 & 1.85 & 0.40 & 0.47 \\
\hline O site & 3.00 & 3.00 & 2.00 & 2.00 \\
\hline $\mathrm{Ca}$ & 0.00 & 0.00 & 0.00 & 0.00 \\
\hline $\mathrm{Na}$ & 0.01 & 0.01 & 0.07 & 0.01 \\
\hline $\mathrm{K}$ & 0.10 & 0.24 & 0.17 & 0.07 \\
\hline $\mathrm{Rb}$ & 0.03 & 0.02 & 0.03 & 0.02 \\
\hline Cs & 0.90 & 0.72 & 0.68 & 0.94 \\
\hline Interlayer & 1.04 & 0.99 & 0.95 & 1.05 \\
\hline$F$ & 1.86 & 1.95 & 1.71 & 1.82 \\
\hline $\mathrm{OH}$ calc & 0.14 & 0.05 & 0.29 & 0.18 \\
\hline Anions & 2.00 & 2.00 & 2.00 & 2.00 \\
\hline
\end{tabular}

* Determined by stoichiometry assuming

$\mathrm{Si}+\mathrm{Al}+\mathrm{Fe}+\mathrm{Mg}+\mathrm{Mn}+\mathrm{Li}=6$ apfu in dioctahedral micas (muscovite I, II, and III; and F-analogue of nanpingite) and $\mathrm{Si}+\mathrm{Al}+\mathrm{Fe}+\mathrm{Mg}+\mathrm{Mn}+\mathrm{Li}=7$ apfu in trioctahedral micas (sokolovaite). $\mathrm{H}_{2} \mathrm{O}$ proportions were also calculated by stoichiometry assuming $(\mathrm{OH}+\mathrm{F})=2$ anions per formula unit.

light. They are optically zoned, with darker cores and paler rims.

Most of the compositions can be classified as Fe-rich elbaite following the scheme of Henry et al. (2011), but the cores of some crystals fall into the schorl field (Table 3). Manganese, usually close to $1 \mathrm{wt} . \%$ (as $\mathrm{MnO})$, can attain 1.59 wt.\% (0.22 apfu). The Mg content is very low and approximately constant, whereas $\mathrm{Ti}$ is generally below the microprobe detection limit $(0.03$ wt. $\% \mathrm{TiO}_{2}$ ). Manganese is positively correlated with $\mathrm{F}$, in contrast with the behavior observed by Bosi et al. (2012) for tsilaisite, the Mn-dominant member of the tourmaline supergroup. Iron and Mn show an inverse correlation.

Regarding the $X$ site, the dominant cation is $\mathrm{Na}$, with low amounts of $\mathrm{Ca}$ and approximately $20 \%$ vacancies. The fractionation trend, as shown in Figure 6, is towards enrichment in $\mathrm{F}, \mathrm{Mn}, \mathrm{Li}$, and $\mathrm{Al}$ together with $\mathrm{Fe}$ depletion. Minor and trace elements $(\mathrm{Mg}, \mathrm{Ti}, \mathrm{Zn}, \mathrm{K})$ do not show a consistent trend across the crystals.

\section{Columbite-group minerals}

The columbite-group minerals occur as anhedral equant to short prismatic crystals, usually mm-sized but up to $1 \mathrm{~cm}$ long. Compositionally, they are classified as columbite-(Mn), with \#Mn [molar ratio of $\mathrm{Mn}$ / $(\mathrm{Mn}+\mathrm{Fe})$ ] very close to 1 and \#Ta [molar ratio of $\mathrm{Ta} /$ $(\mathrm{Ta}+\mathrm{Nb})$ ] between 0.186 and 0.195 (Table 4). Wise $e t$ al. (2012) identified a trend of fast Mn increase prior to the extreme Ta enrichment in pegmatites with abundant lepidolite-bearing units (Maine, USA). Trends like this have also been identified by other authors (Černý 1989). Columbite-(Mn) from the replacement unit of the Ángel pegmatite may correspond to an intermediate step of this trend, with high \#Mn and rather low \#Ta, occurring along with micas only slightly enriched in $\mathrm{Li}$ (muscovite II).

\section{Microlite-group minerals (MGM)}

The MGM occur as rounded crystals between 50 and $300 \mu \mathrm{m}$ in diameter, or filling veinlets in columbite$(\mathrm{Mn})$. They frequently show secondary alteration and metamictization. Compositions (Table 4) show Ta and $\mathrm{Nb}$ ranging from 1.35 to $1.44 \mathrm{apfu}$ and from 0.54 to $0.63 \mathrm{apfu}$, respectively. Substitutions of Ti and other elements at the $B$ site are limited to a maximum of $1 \%$ of atoms per formula unit. The $A$ site is dominated by vacancies, while the sum of cations occupying this site generally does not exceed $1 \mathrm{apfu}$. In order of decreasing abundance, the $A$ site is occupied by $\mathrm{U}(0.36-0.38$ $a p f u), \mathrm{Ca}(0.21-0.24 a p f u), \mathrm{Bi}(0.09-0.12$ apfu), and $\mathrm{Na}$ (0.02-0.06 apfu), with very minor amounts of Th, La, $\mathrm{Ce}, \mathrm{Al}, \mathrm{Fe}, \mathrm{Mn}$, and $\mathrm{Ba}$. Several EDS spectra confirmed that no other elements with $\mathrm{Z}>11$ were present. Therefore, we conclude that vacancies dominate at the $A$ site. Assuming that the $Y$ site is fully occupied by $(\mathrm{OH}+\mathrm{F}+\mathrm{K})$, then the $(\mathrm{OH})^{-}$anions dominate this site (0.56 apfu on average), with F contents attaining 0.46 apfu (Table 4). Hence, these grains can be classified as hydroxykenomicrolite, according to the scheme of Atencio et al. (2010). 


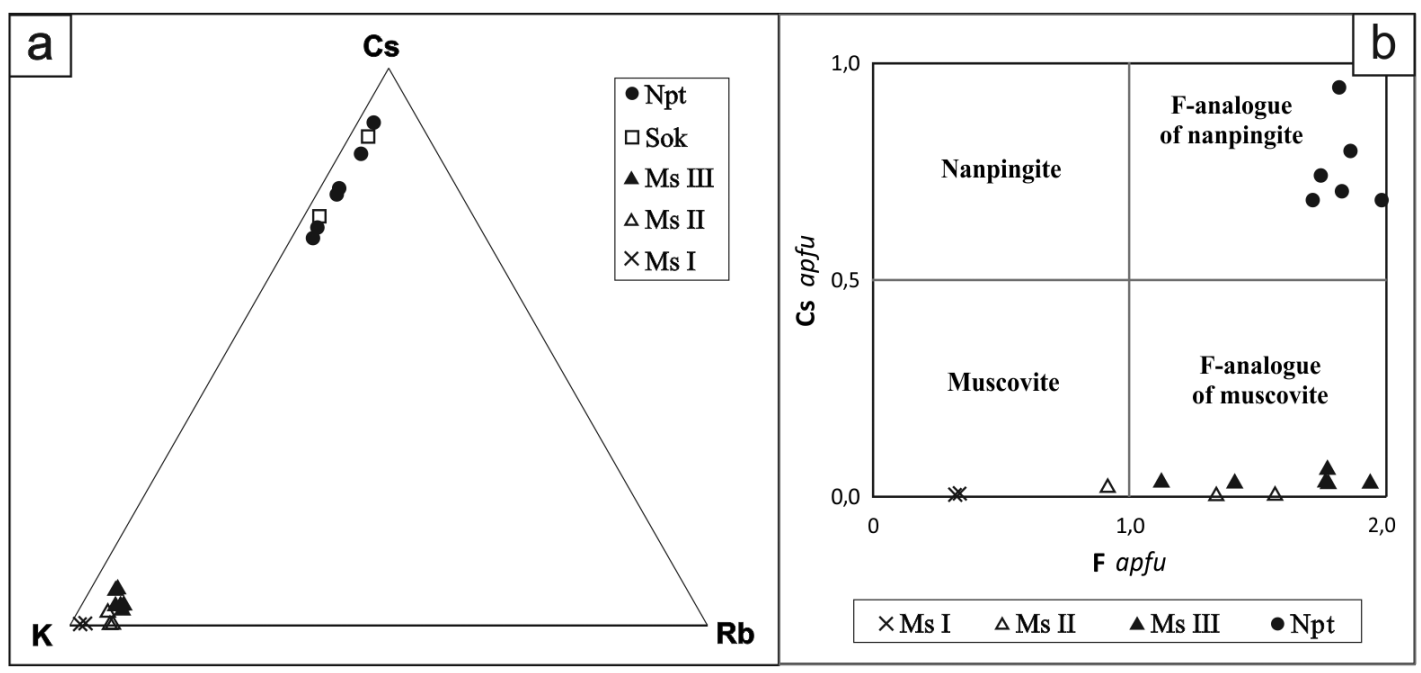

FIG. 5. (a) Triangular plot of the relative proportions of interlayer cation in the different micas. Note the extreme Cs-enrichment in the sokolovaites and the F-analogue of nanpingites. (b) Classification of micas according to their relative proportions of $\mathrm{F}$ and Cs. Abbreviations in both figures are as follows: Ms I, II and III = muscovite I, II and III; Sok = sokolovaite; Npt = F-analogue of nanpingite.

\section{Zircon}

Zircon was observed in all samples, where it occurs as relatively large (between $100 \mu \mathrm{m}$ and $1 \mathrm{~mm}$ in diameter) euhedral to subhedral zoned grains. Three compositional domains have been identified in the zircon crystals using BSE images and EPMA analyses: relics of zircon and hafnian zircon in the crystal cores and rims, respectively, and heterogeneously textured domains of non-stoichiometric, probably hydrated zircon (Figs. 7a-d).

Both the relict zircon cores and hafnian zircon rims have almost stoichiometric compositions, with analytical totals close to $100 \%$. The substitution of Si by $\mathrm{P}$ and $\mathrm{Al}$ at the tetrahedral sites and the incorporation of cations other than $\mathrm{Zr}$ and $\mathrm{Hf}$ at the eightfold-coordinated site are negligible (Table 5). Silicon contents are generally higher than 0.95 apfu (on the basis of $4 \mathrm{O} a p f u$ ), and the sum of $\mathrm{Zr}+\mathrm{Hf}$ is always near 1 apfu. The Hf content varies from 11.5 to 14.19 wt. $\% \mathrm{HfO}_{2}(0.11$ to $0.13 \mathrm{Hf} a p f u)$ in zircon cores, with $\mathrm{Hf} /(\mathrm{Zr}+\mathrm{Hf})$ values between 0.10 and 0.13 . By contrast, hafnian zircon rims display $\mathrm{Hf}$ contents from 18.77 to 29.84 wt. $\% \mathrm{HfO}_{2}$ (from 0.18 to $0.31 \mathrm{Hf} a p f u$ ), and $\mathrm{Hf} /(\mathrm{Zr}+\mathrm{Hf})$ values between 0.18 and 0.29 (Table 5). According to the nomenclature proposed by Correia Neves et al. (1974), both domains correspond to hafnian zircon (between 10 and $50 \mathrm{~mol} . \%$ of the "hafnon" component), with the cores being very close to zircon composition (between 0 and 10 mol.\% of the "hafnon" component). No textures suggesting metamictization were detected in the BSE images, and both $\mathrm{U}$ and $\mathrm{Th}$ were below the microprobe detection limit.

Domains with heterogeneous textures, commonly observed in the interior parts of the zircon crystals, display variable grey tones in BSE images due to compositional inhomogeneities. These areas are erratically distributed within the crystals and do not follow any preferential orientation (Figs. $7 \mathrm{a}-\mathrm{d}$ ). Thin veins of alteration material connect these internal heterogeneous domains with a secondary $\mathrm{Zr}$ - and Hf-bearing phosphate mineral (Fig. 7b), indicating a genetic link between them. Microprobe analyses obtained from these domains revealed a non-stoichiometric composition, with analytical totals generally below $90 \%$. Unlike the stoichiometric zones described above, the rapid decay produced by the electron beam during the EPMA analyses evidenced structural weaknesses in these domains, probably due to the incorporation of $\mathrm{H}_{2} \mathrm{O}$ into the structure, which also explains the low totals of the analyses, as was suggested by other authors (Pointer et al. 1988). Since all of the elements detected by EDS were included in the analytical routine, the presence of $\mathrm{H}_{2} \mathrm{O}$ or hydroxyl anions in the structure

FIG. 6. BSE images and cation contents of zoned tourmalines. (a) and (b) BSE images of zoned tourmaline crystals with the location of analyses numbers. (c) and (d) $\mathrm{Fe}^{+}, \mathrm{Al}, \mathrm{Li}$, and Mn. (e) and (f) Na and Ca. (g) and (h) F. 


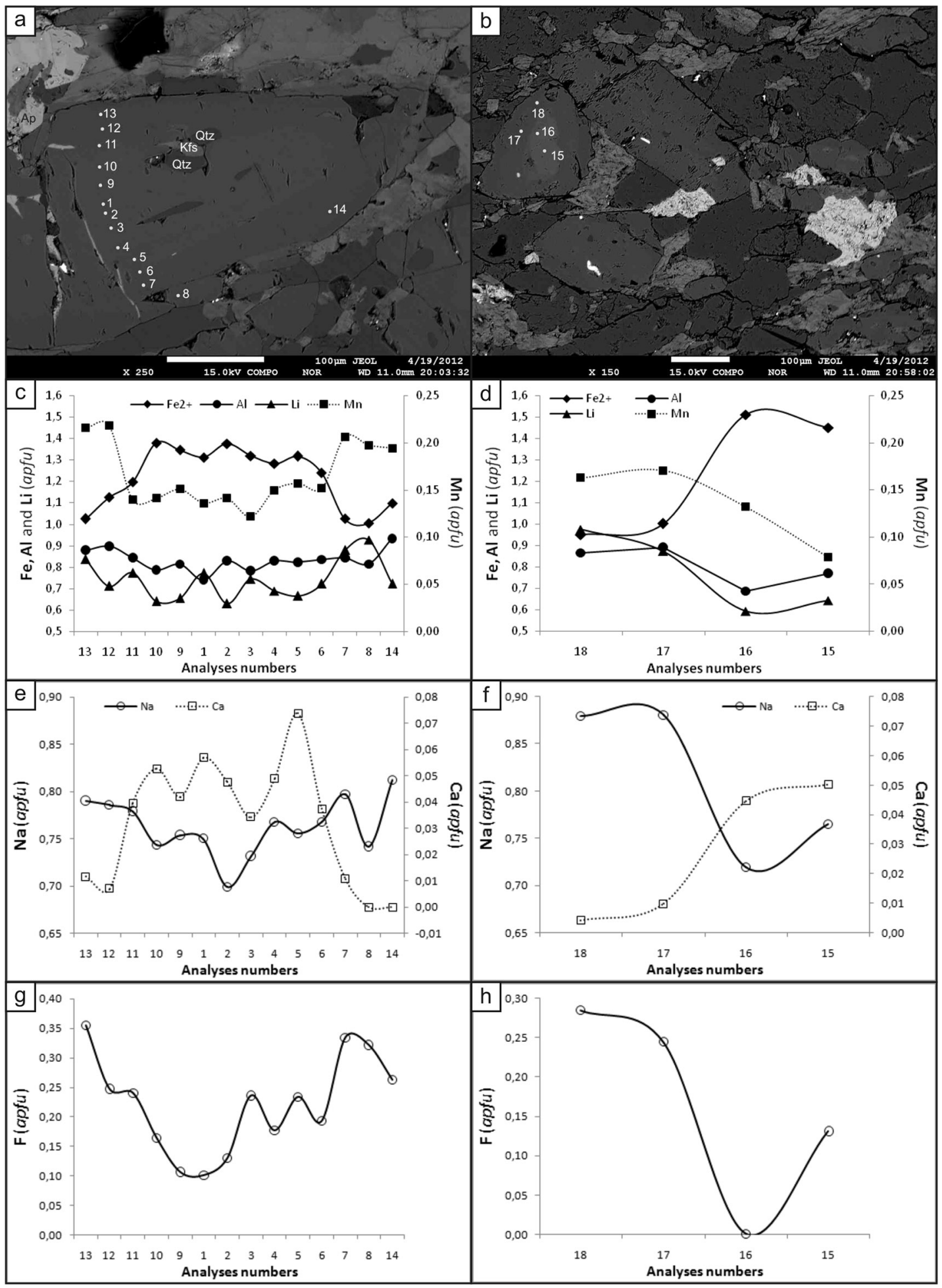


TABLE 3. ELECTRON MICROPROBE ANALYSES OF TOURMALINE

\begin{tabular}{lrrrrrrrr}
\hline & \multicolumn{1}{c}{7} & \multicolumn{1}{c}{6} & \multicolumn{1}{c}{5} & \multicolumn{1}{c}{4} & 3 & 2 & 1 \\
\hline $\mathrm{SiO}_{2}$ wt. \% & 37.01 & 37.07 & 36.51 & 36.00 & 36.33 & 36.64 & 36.17 & 36.91 \\
$\mathrm{TiO}_{2}$ & 0.04 & 0.04 & 0.07 & 0.04 & 0.00 & 0.00 & 0.00 & 0.00 \\
$\mathrm{Al}_{2} \mathrm{O}_{3}$ & 35.14 & 35.56 & 35.25 & 35.50 & 35.20 & 34.91 & 35.01 & 34.95 \\
$\mathrm{Cr}_{2} \mathrm{O}_{3}$ & 0.00 & 0.00 & 0.00 & 0.00 & 0.00 & 0.00 & 0.00 & 0.00 \\
$\mathrm{FeO}$ & 7.30 & 7.51 & 9.00 & 9.55 & 9.30 & 9.57 & 9.93 & 9.59 \\
$\mathrm{MgO}$ & 0.14 & 0.18 & 0.19 & 0.14 & 0.15 & 0.14 & 0.10 & 0.13 \\
$\mathrm{CaO}$ & 0.00 & 0.06 & 0.21 & 0.42 & 0.28 & 0.19 & 0.27 & 0.33 \\
$\mathrm{MnO}$ & 1.42 & 1.49 & 1.09 & 1.13 & 1.07 & 0.87 & 1.00 & 0.98 \\
$\mathrm{ZnO}$ & 0.15 & 0.00 & 0.00 & 0.00 & 0.13 & 0.00 & 0.00 & 0.08 \\
$\mathrm{Na}_{2} \mathrm{O}$ & 2.33 & 2.52 & 2.41 & 2.37 & 2.40 & 2.29 & 2.18 & 2.36 \\
$\mathrm{~K}_{2} \mathrm{O}$ & 0.04 & 0.01 & 0.01 & 0.00 & 0.02 & 0.02 & 0.02 & 0.04 \\
$\mathrm{Bi}_{2} \mathrm{O}_{3}$ & 0.00 & 0.00 & 0.00 & 0.00 & 0.00 & 0.00 & 0.09 & 0.00 \\
$\mathrm{~F}$ & 0.62 & 0.65 & 0.37 & 0.45 & 0.34 & 0.45 & 0.25 & 0.20 \\
$\mathrm{H}_{2} \mathrm{O}^{*}$ & 3.35 & 3.37 & 3.47 & 3.43 & 3.48 & 3.42 & 3.50 & 3.57 \\
$\mathrm{~B}_{2} \mathrm{O}_{3}{ }^{*}$ & 10.57 & 10.65 & 10.57 & 10.55 & 10.54 & 10.54 & 10.49 & 10.62 \\
$\mathrm{Li}_{2} \mathrm{O}^{*}$ & 1.40 & 1.34 & 1.09 & 1.00 & 1.04 & 1.12 & 0.95 & 1.17 \\
$-\mathrm{O}^{*} \mathrm{~F}$ & -0.26 & -0.27 & -0.16 & -0.19 & -0.14 & -0.19 & -0.10 & -0.08 \\
$\mathrm{Total}$ & 99.24 & 100.16 & 100.08 & 100.38 & 100.12 & 99.98 & 99.85 & 100.84
\end{tabular}

Structural formula based on 31 anions $(\mathrm{O}, \mathrm{OH}, \mathrm{F})$ in apfu

\begin{tabular}{|c|c|c|c|c|c|c|c|c|}
\hline \multicolumn{9}{|l|}{$T$ site } \\
\hline $\mathrm{Si}$ & 6.089 & 6.052 & 6.006 & 5.931 & 5.990 & 6.040 & 5.992 & 6.040 \\
\hline $\mathrm{Al}$ & 0.000 & 0.000 & 0.000 & 0.069 & 0.010 & 0.000 & 0.008 & 0.000 \\
\hline \multicolumn{9}{|l|}{$B$ site } \\
\hline B & 3.000 & 3.000 & 3.000 & 3.000 & 3.000 & 3.000 & 3.000 & 3.000 \\
\hline \multicolumn{9}{|l|}{$Z$ site } \\
\hline $\mathrm{Al}$ & 6.000 & 6.000 & 6.000 & 6.000 & 6.000 & 6.000 & 6.000 & 6.000 \\
\hline $\mathrm{Mg}$ & 0.000 & 0.000 & 0.000 & 0.000 & 0.000 & 0.000 & 0.000 & 0.000 \\
\hline \multicolumn{9}{|l|}{$Y$ site } \\
\hline $\mathrm{Al}$ & 0.813 & 0.841 & 0.834 & 0.823 & 0.829 & 0.782 & 0.828 & 0.740 \\
\hline $\mathrm{Ti}$ & 0.005 & 0.005 & 0.008 & 0.004 & 0.000 & 0.000 & 0.000 & 0.000 \\
\hline $\mathrm{Mg}$ & 0.035 & 0.044 & 0.047 & 0.035 & 0.036 & 0.033 & 0.026 & 0.031 \\
\hline $\mathrm{Mn}$ & 0.197 & 0.206 & 0.151 & 0.157 & 0.149 & 0.122 & 0.141 & 0.136 \\
\hline $\mathrm{Fe}^{2+}$ & 1.005 & 1.025 & 1.238 & 1.316 & 1.282 & 1.319 & 1.376 & 1.312 \\
\hline $\mathrm{Zn}$ & 0.018 & 0.000 & 0.000 & 0.000 & 0.015 & 0.000 & 0.000 & 0.010 \\
\hline $\mathrm{Li}^{*}$ & 0.927 & 0.879 & 0.721 & 0.665 & 0.688 & 0.744 & 0.630 & 0.771 \\
\hline$\sum Y$ & 3.000 & 3.000 & 3.000 & 3.000 & 3.000 & 3.000 & 3.000 & 3.000 \\
\hline \multicolumn{9}{|l|}{$X$ site } \\
\hline $\mathrm{Ca}$ & 0.000 & 0.011 & 0.037 & 0.074 & 0.049 & 0.034 & 0.048 & 0.057 \\
\hline $\mathrm{Na}$ & 0.742 & 0.797 & 0.768 & 0.755 & 0.767 & 0.732 & 0.699 & 0.750 \\
\hline $\mathrm{K}$ & 0.008 & 0.002 & 0.002 & 0.000 & 0.004 & 0.004 & 0.004 & 0.008 \\
\hline $\mathrm{Bi}$ & 0.000 & 0.000 & 0.000 & 0.000 & 0.000 & 0.000 & 0.004 & 0.000 \\
\hline Xvac. & 0.251 & 0.190 & 0.193 & 0.171 & 0.179 & 0.231 & 0.246 & 0.185 \\
\hline \multicolumn{9}{|l|}{$V+W$ site } \\
\hline $\mathrm{OH}$ & 3.678 & 3.666 & 3.807 & 3.766 & 3.823 & 3.764 & 3.870 & 3.899 \\
\hline $\mathrm{F}$ & 0.322 & 0.334 & 0.193 & 0.234 & 0.177 & 0.236 & 0.130 & 0.101 \\
\hline
\end{tabular}

Classification Elbaite Elbaite Elbaite Elbaite Elbaite Elbaite Elbaite Elbaite

Analyses 1 to 13 were made line perpendicular to the $\mathbf{c}$ axis (see Fig. 6). The numbers of the analyses shown in the table follow the analytical sequence from lower rim to upper rim, as shown in Figure 6. See text for details on $\mathrm{Li}, \mathrm{H}_{2} \mathrm{O}$, and $\mathrm{B}$ calculations. Chromium was below the detection limit. 
TABLE 3 (CONTINUED). ELECTRON MICROPROBE ANALYSES OF TOURMALINE

\begin{tabular}{|c|c|c|c|c|c|c|c|c|c|c|}
\hline & 9 & 10 & 11 & 12 & 13 & 14 & 15 & 16 & 17 & 18 \\
\hline $\mathrm{SiO}_{2}$ wt. $\%$ & 36.44 & 36.26 & 36.91 & 37.01 & 36.97 & 36.18 & 35.75 & 35.76 & 36.57 & 37.02 \\
\hline $\mathrm{TiO}_{2}$ & 0.00 & 0.03 & 0.01 & 0.00 & 0.00 & 0.00 & 0.00 & 0.00 & 0.00 & 0.00 \\
\hline $\mathrm{Al}_{2} \mathrm{O}_{3}$ & 35.12 & 35.04 & 35.62 & 36.08 & 35.76 & 35.76 & 34.22 & 33.69 & 35.53 & 35.61 \\
\hline $\mathrm{Cr}_{2} \mathrm{O}_{3}$ & 0.00 & 0.00 & 0.00 & 0.00 & 0.00 & 0.00 & 0.00 & 0.00 & 0.00 & 0.00 \\
\hline $\mathrm{FeO}$ & 9.78 & 10.00 & 8.77 & 8.29 & 7.51 & 7.95 & 10.33 & 10.72 & 7.28 & 6.95 \\
\hline $\mathrm{MgO}$ & 0.12 & 0.14 & 0.14 & 0.15 & 0.14 & 0.16 & 0.23 & 0.23 & 0.18 & 0.15 \\
\hline $\mathrm{CaO}$ & 0.24 & 0.30 & 0.23 & 0.04 & 0.07 & 0.00 & 0.28 & 0.25 & 0.06 & 0.02 \\
\hline $\mathrm{MnO}$ & 1.08 & 1.01 & 1.01 & 1.59 & 1.56 & 1.39 & 0.55 & 0.93 & 1.22 & 1.18 \\
\hline $\mathrm{ZnO}$ & 0.06 & 0.12 & 0.11 & 0.11 & 0.10 & 0.11 & 0.00 & 0.16 & 0.14 & 0.08 \\
\hline $\mathrm{Na}_{2} \mathrm{O}$ & 2.36 & 2.33 & 2.47 & 2.50 & 2.50 & 2.54 & 2.35 & 2.20 & 2.76 & 2.77 \\
\hline $\mathrm{K}_{2} \mathrm{O}$ & 0.03 & 0.04 & 0.01 & 0.01 & 0.03 & 0.02 & 0.01 & 0.03 & 0.02 & 0.00 \\
\hline $\mathrm{Bi}_{2} \mathrm{O}_{3}$ & 0.00 & 0.09 & 0.00 & 0.00 & 0.00 & 0.00 & 0.00 & 0.00 & 0.00 & 0.00 \\
\hline $\mathrm{F}$ & 0.21 & 0.32 & 0.47 & 0.48 & 0.69 & 0.50 & 0.25 & 0.00 & 0.47 & 0.55 \\
\hline $\mathrm{H}_{2} \mathrm{O}^{*}$ & 3.55 & 3.49 & 3.46 & 3.47 & 3.35 & 3.39 & 3.45 & 3.56 & 3.42 & 3.41 \\
\hline $\mathrm{B}_{2} \mathrm{O}_{3}{ }^{*}$ & 10.56 & 10.54 & 10.66 & 10.71 & 10.65 & 10.53 & 10.35 & 10.32 & 10.56 & 10.63 \\
\hline $\mathrm{Li}_{2} \mathrm{O}^{*}$ & 0.99 & 0.97 & 1.18 & 1.09 & 1.27 & 1.09 & 0.95 & 0.88 & 1.32 & 1.4 \\
\hline$-\mathrm{O}=\mathrm{F}$ & -0.09 & -0.13 & -0.20 & -0.20 & -0.29 & -0.21 & -0.10 & 0.00 & -0.20 & -0.23 \\
\hline Total & 100.42 & 100.53 & 100.84 & 101.32 & 100.31 & 99.39 & 98.61 & 98.72 & 99.32 & 99.61 \\
\hline
\end{tabular}

Structural formula based on 31 anions $(\mathrm{O}, \mathrm{OH}, \mathrm{F})$ in apfu

\begin{tabular}{|c|c|c|c|c|c|c|c|c|c|c|}
\hline \multicolumn{11}{|l|}{$T$ site } \\
\hline $\mathrm{Si}$ & 5.998 & 5.979 & 6.017 & 6.003 & 6.034 & 5.974 & 6.001 & 6.023 & 6.019 & 6.056 \\
\hline $\mathrm{Al}$ & 0.002 & 0.021 & 0.000 & 0.000 & 0.000 & 0.026 & 0.000 & 0.000 & 0.000 & 0.000 \\
\hline \multicolumn{11}{|l|}{$B$ site } \\
\hline B & 3.000 & 3.000 & 3.000 & 3.000 & 3.000 & 3.000 & 3.000 & 3.000 & 3.000 & 3.000 \\
\hline \multicolumn{11}{|l|}{$Z$ site } \\
\hline $\mathrm{Al}$ & 6.000 & 6.000 & 6.000 & 6.000 & 6.000 & 6.000 & 6.000 & 6.000 & 6.000 & 6.000 \\
\hline $\mathrm{Mg}$ & 0.000 & 0.000 & 0.000 & 0.000 & 0.000 & 0.000 & 0.000 & 0.000 & 0.000 & 0.000 \\
\hline \multicolumn{11}{|l|}{$Y$ site } \\
\hline $\mathrm{Al}$ & 0.813 & 0.786 & 0.843 & 0.898 & 0.879 & 0.933 & 0.771 & 0.687 & 0.892 & 0.865 \\
\hline $\mathrm{Ti}$ & 0.000 & 0.004 & 0.001 & 0.000 & 0.000 & 0.000 & 0.000 & 0.000 & 0.000 & 0.000 \\
\hline $\mathrm{Mg}$ & 0.029 & 0.034 & 0.035 & 0.035 & 0.035 & 0.040 & 0.057 & 0.057 & 0.044 & 0.036 \\
\hline $\mathrm{Mn}$ & 0.151 & 0.141 & 0.139 & 0.218 & 0.215 & 0.194 & 0.078 & 0.132 & 0.170 & 0.163 \\
\hline $\mathrm{Fe} 2+$ & 1.346 & 1.379 & 1.196 & 1.125 & 1.024 & 1.098 & 1.450 & 1.510 & 1.002 & 0.951 \\
\hline $\mathrm{Zn}$ & 0.007 & 0.015 & 0.013 & 0.013 & 0.012 & 0.013 & 0.000 & 0.020 & 0.017 & 0.010 \\
\hline $\mathrm{Li}^{*}$ & 0.654 & 0.640 & 0.773 & 0.711 & 0.835 & 0.722 & 0.644 & 0.594 & 0.874 & 0.976 \\
\hline$\sum Y$ & 3.000 & 3.000 & 3.000 & 3.000 & 3.000 & 3.000 & 3.000 & 3.000 & 3.000 & 3.000 \\
\hline \multicolumn{11}{|l|}{$X$ site } \\
\hline $\mathrm{Ca}$ & 0.042 & 0.053 & 0.040 & 0.007 & 0.012 & 0.000 & 0.050 & 0.045 & 0.010 & 0.004 \\
\hline $\mathrm{Na}$ & 0.754 & 0.744 & 0.779 & 0.786 & 0.790 & 0.812 & 0.765 & 0.719 & 0.881 & 0.879 \\
\hline $\mathrm{K}$ & 0.005 & 0.008 & 0.002 & 0.002 & 0.007 & 0.003 & 0.002 & 0.006 & 0.004 & 0.000 \\
\hline $\mathrm{Bi}$ & 0.000 & 0.004 & 0.000 & 0.000 & 0.000 & 0.000 & 0.000 & 0.000 & 0.000 & 0.000 \\
\hline Xvac. & 0.199 & 0.192 & 0.179 & 0.206 & 0.191 & 0.185 & 0.183 & 0.231 & 0.106 & 0.117 \\
\hline \multicolumn{11}{|l|}{$V+W$ site } \\
\hline $\mathrm{OH}$ & 3.893 & 3.836 & 3.760 & 3.753 & 3.645 & 3.737 & 3.869 & 3.999 & 3.755 & 3.715 \\
\hline $\mathrm{F}$ & 0.107 & 0.164 & 0.240 & 0.247 & 0.355 & 0.263 & 0.131 & 0.001 & 0.245 & 0.285 \\
\hline
\end{tabular}

Classification Elbaite Elbaite Elbaite Elbaite Elbaite Elbaite Schorl Schorl Elbaite Elbaite

Analyses 1 to 13 were made along a line perpendicular to the $\mathbf{c}$ axis (see Fig. 6). The numbers of the analyses shown in the table follow the analytical sequence from lower rim to upper rim, as shown in Figure 6. See text for details on $\mathrm{Li}, \mathrm{H}_{2} \mathrm{O}$, and B calculations. Chromium and $\mathrm{Bi}$ were below the detection limits. 
TABLE 4. REPRESENTATIVE ANALYSES OF COLUMBITE-GROUP MINERALS AND MICROLITE-GROUP MINERALS FROM THE REPLACEMENT UNIT OF THE ÁNGEL PEGMATITE

\begin{tabular}{|c|c|c|c|c|c|c|c|c|c|}
\hline & \multicolumn{4}{|c|}{ Columbite-group minerals } & & \multicolumn{3}{|c|}{ Microlite-group minerals } & \multirow{2}{*}{ Average } \\
\hline & 1 & 2 & 3 & 4 & & 1 & 2 & 3 & \\
\hline $\mathrm{MnO}$ wt.\% & 18.63 & 18.36 & 18.88 & 19.27 & $\mathrm{Nb}_{2} \mathrm{O}_{5}$ & 15.37 & 13.37 & 15.35 & \\
\hline $\mathrm{FeO}$ & 0.13 & 0.09 & 0.03 & 0.04 & $\mathrm{Ta}_{2} \mathrm{O}_{5}$ & 55.13 & 59.21 & 56.18 & \\
\hline $\mathrm{Nb}_{2} \mathrm{O}_{5}$ & 57.91 & 56.97 & 58.37 & 57.57 & $\mathrm{TiO}_{2}$ & 0.00 & 0.02 & 0.00 & \\
\hline $\mathrm{Ta}_{2} \mathrm{O}_{5}$ & 22.18 & 22.99 & 22.18 & 22.51 & $\mathrm{UO}_{2}$ & 18.72 & 17.93 & 18.27 & \\
\hline \multirow[t]{2}{*}{ Total } & 98.84 & 98.4 & 99.47 & 99.39 & $\mathrm{ThO}_{2}$ & 0.03 & 0.14 & 0.00 & \\
\hline & & & & & $\mathrm{La}_{2} \mathrm{O}_{3}$ & 0.13 & 0.04 & 0.03 & \\
\hline Mn apfu & 0.98 & 0.98 & 0.99 & 1.01 & $\mathrm{Ce}_{2} \mathrm{O}_{3}$ & 0.21 & 0.22 & 0.17 & \\
\hline $\mathrm{Fe}$ & 0.01 & 0.00 & 0.00 & 0.00 & $\mathrm{Bi}_{2} \mathrm{O}_{3}$ & 5.14 & 4.02 & 4.93 & \\
\hline$\Sigma A$ site & 0.99 & 0.98 & 0.99 & 1.01 & $\mathrm{Al}_{2} \mathrm{O}_{3}$ & 0.18 & 0.14 & 0.17 & \\
\hline $\mathrm{Nb}$ & 1.63 & 1.62 & 1.63 & 1.61 & $\mathrm{FeO}$ & 0.00 & 0.07 & 0.00 & \\
\hline $\mathrm{Ta}$ & 0.38 & 0.39 & 0.37 & 0.38 & $\mathrm{MnO}$ & 0.08 & 0.06 & 0.07 & \\
\hline \multirow[t]{2}{*}{$\Sigma B$ site } & 2.00 & 2.01 & 2.00 & 1.99 & $\mathrm{CaO}$ & 2.50 & 2.20 & 2.17 & \\
\hline & & & & & $\mathrm{BaO}$ & 0.09 & 0.00 & 0.00 & \\
\hline $\mathrm{Mn} /(\mathrm{Mn}+\mathrm{Fe})$ & 0.99 & 1.00 & 1.00 & 1.00 & $\mathrm{Na}_{2} \mathrm{O}$ & 0.36 & 0.10 & 0.25 & \\
\hline \multirow[t]{29}{*}{$\mathrm{Ta} /(\mathrm{Ta}+\mathrm{Nb})$} & 0.19 & 0.20 & 0.19 & 0.19 & $\mathrm{~K}_{2} \mathrm{O}$ & 0.04 & 0.00 & 0.04 & \\
\hline & & & & & $\mathrm{F}$ & 1.55 & 1.63 & 1.49 & \\
\hline & & & & & $\mathrm{H}_{2} \mathrm{O}$ * & 0.92 & 0.90 & 0.97 & \\
\hline & & & & & $-\mathrm{O}=\mathrm{F}$ & 0.65 & 0.69 & 0.63 & \\
\hline & & & & & TOTAL & 99.79 & 99.36 & 99.44 & \\
\hline & & & & & A site & & & & \\
\hline & & & & & $\mathrm{Na}$ & 0.06 & 0.02 & 0.04 & 0.04 \\
\hline & & & & & $\mathrm{Ca}$ & 0.24 & 0.21 & 0.21 & 0.22 \\
\hline & & & & & $\mathrm{Mn}$ & 0.01 & 0.01 & 0.01 & 0.01 \\
\hline & & & & & $\mathrm{Ba}$ & 0.00 & 0.00 & 0.00 & 0.00 \\
\hline & & & & & $\mathrm{Fe}^{++}$ & 0.00 & 0.01 & 0.00 & 0.00 \\
\hline & & & & & $\mathrm{Bi}^{++}$ & 0.12 & 0.09 & 0.11 & 0.11 \\
\hline & & & & & $\mathrm{Ce}$ & 0.01 & 0.01 & 0.01 & 0.01 \\
\hline & & & & & $\mathrm{La}$ & 0.00 & 0.00 & 0.00 & 0.00 \\
\hline & & & & & $U$ & 0.38 & 0.36 & 0.36 & 0.37 \\
\hline & & & & & Th & 0.00 & 0.00 & 0.00 & 0.00 \\
\hline & & & & & $\Sigma A$ & 0.82 & 0.70 & 0.74 & 0.75 \\
\hline & & & & & B site & & & & \\
\hline & & & & & $\mathrm{Ta}$ & 1.35 & 1.44 & 1.36 & 1.38 \\
\hline & & & & & $\mathrm{Nb}$ & 0.63 & 0.54 & 0.62 & 0.60 \\
\hline & & & & & $\mathrm{Ti}$ & 0.00 & 0.00 & 0.00 & 0.00 \\
\hline & & & & & $\mathrm{Al}$ & 0.02 & 0.02 & 0.02 & 0.02 \\
\hline & & & & & $\Sigma B$ & 2.00 & 2.00 & 2.00 & 2.00 \\
\hline & & & & & $X+Y$ site & & & & \\
\hline & & & & & 0 & 6.22 & 6.09 & 6.12 & 6.14 \\
\hline & & & & & $\mathrm{F}$ & 0.44 & 0.46 & 0.42 & 0.44 \\
\hline & & & & & $\mathrm{K}$ & 0.00 & 0.00 & 0.00 & 0.00 \\
\hline & & & & & $\mathrm{OH}$ & 0.55 & 0.54 & 0.58 & 0.56 \\
\hline & & & & & $\Sigma(X+Y)$ & 6.66 & 6.55 & 6.55 & 6.59 \\
\hline
\end{tabular}

Formulae of columbite-group minerals calculated based on 8 atoms per formula unit. Formulae of hydroxykenomicrolite calculated based on $\Sigma B=2$ apfu.

*Determined by stoichiometry, assuming that the $(\mathrm{X}+\mathrm{Y})$ sites are fully occupied, i.e., $(\mathrm{K}+\mathrm{F}+\mathrm{OH})$ $=1 \mathrm{apfu}$. 

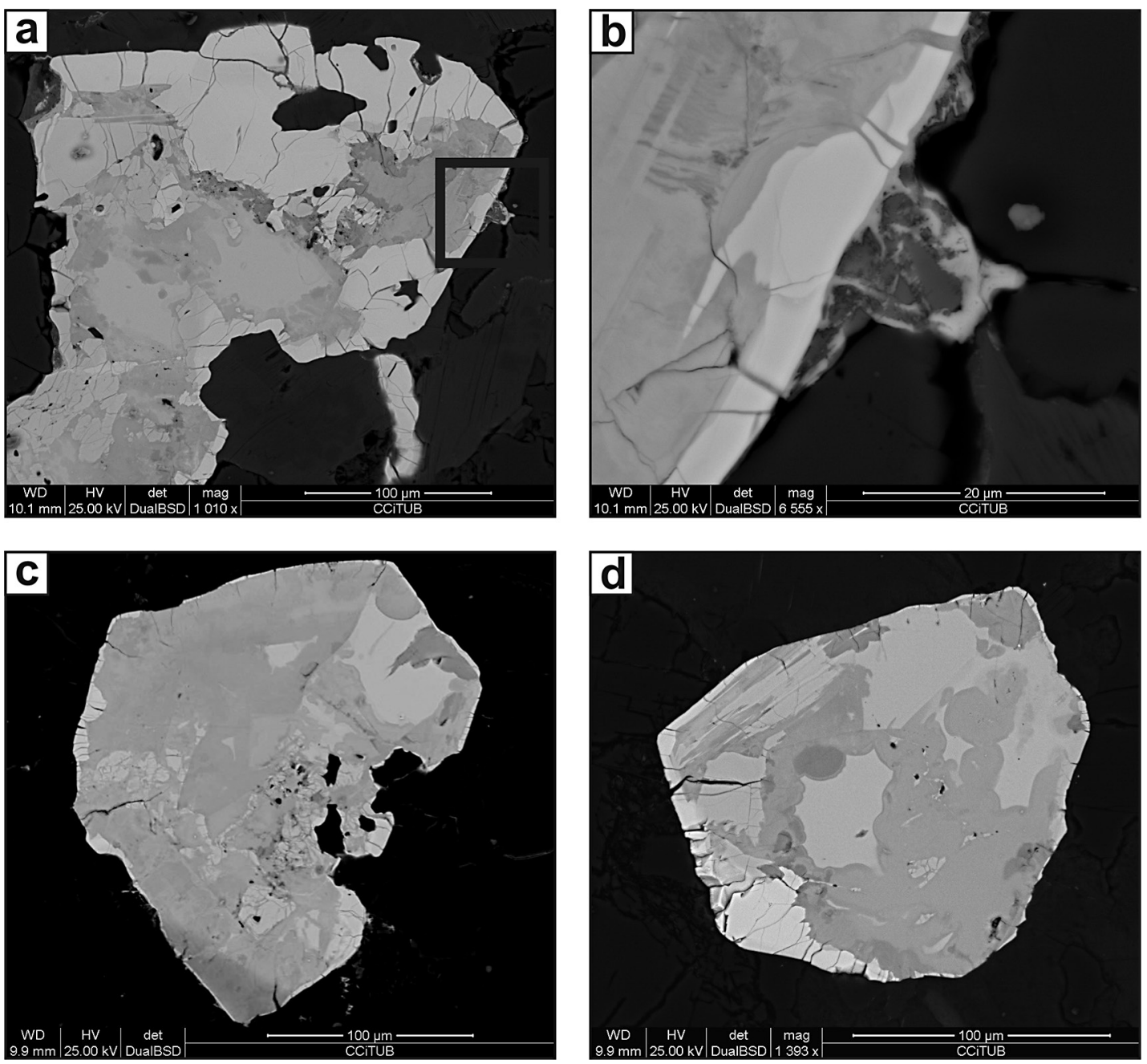

FIG. 7 BSE images of zircon crystals. (a), (c) and (d) Note the hafnian zircon rimming the crystals (paler outer zones) and heterogeneously textured internal domains generated by further alteration. (b) Enlargement of the inset in Figure 7a, with textures indicating secondary processes of alteration of previous zircon crystals.

is probable. Stoichiometric ratios are also typical of altered zircon, with $(\mathrm{Si}+\mathrm{P}+\mathrm{Al})$ below 1 apfu and $(\mathrm{Zr}+\mathrm{Hf}+\mathrm{U})$ and other cations that can enter this eight-fold position above $1 \mathrm{apfu}$, when normalized on a $4 \mathrm{O}$ basis. Phosphorus is notably enriched in these domains, reaching 0.34 apfu (Table 5). Values of $\Sigma T$ site as low as 0.86 were measured. The average sum of $\mathrm{Zr}+\mathrm{Hf}$ is lower than that obtained for the other two zircon types, coupled with a notable enrichment in $\mathrm{Ca}$, $\mathrm{Mn}$, and $\mathrm{Na}$ (up to $3.33,2.82$, and 0.57 wt.\% of their respective oxides).

\section{Pollucite}

Pollucite is a Cs-bearing zeolite that forms a solid solution with analcime and constitutes the principal Cs ore mineral in highly evolved granitic pegmatites. In the studied area, pollucite was found in only one sample from the western part of the replacement unit of the Ángel pegmatite, occurring as small round- to ovalshaped grains, up to $30 \mu \mathrm{m}$ in diameter, always included in quartz (Fig. 8a). The chemical composition of pollucite is presented in Table 6 and Figure $8 \mathrm{~b}$; it shows relatively high contents of Cs and Al. CRK [defined as the molar ratio of $(\mathrm{Cs}+\mathrm{Rb}+\mathrm{K}) /(\mathrm{Mg}+\mathrm{Ca}+\mathrm{Na}+\mathrm{Cs}+\mathrm{Rb}+\mathrm{K})]$ 


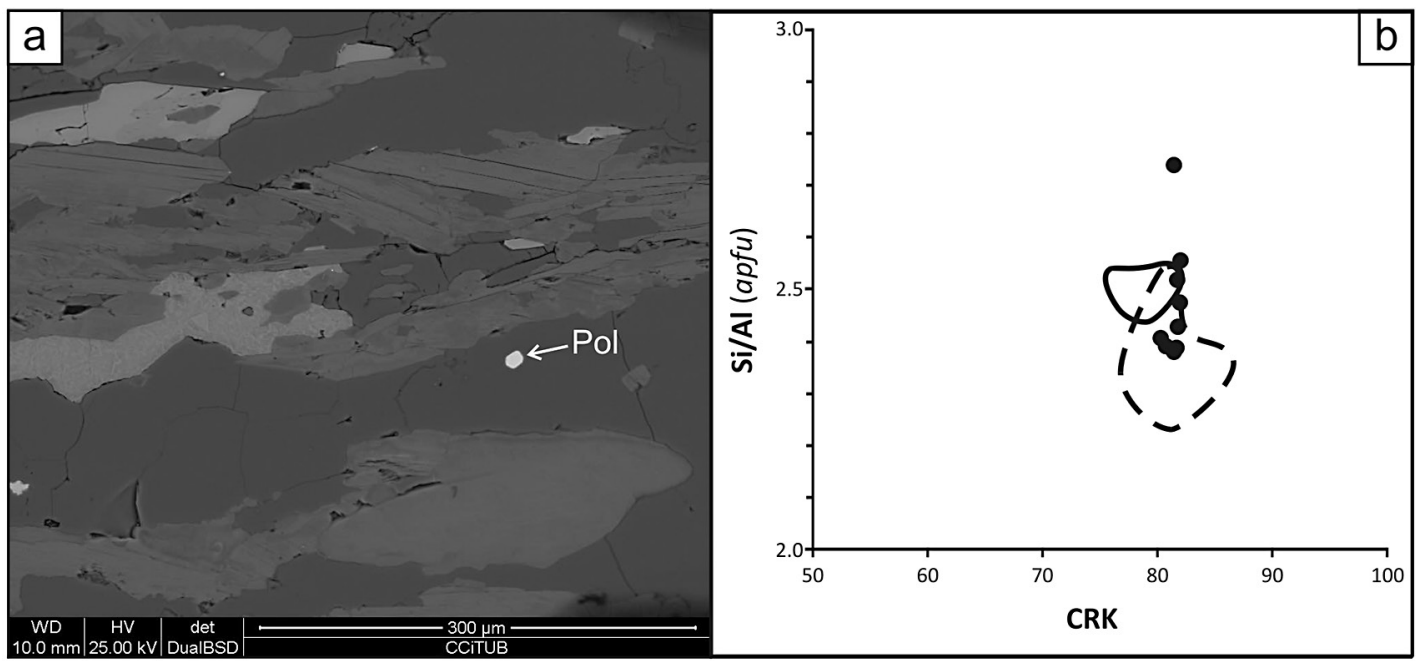

FIG. 8. (a) BSE image of a pollucite (Pol) crystal hosted in quartz. (b) Si/Al versus CRK [defined as the molar ratio of $(\mathrm{Cs}+\mathrm{Rb}+\mathrm{K}) /(\mathrm{Mg}+\mathrm{Ca}+\mathrm{Na}+\mathrm{Cs}+\mathrm{Rb}+\mathrm{K})]$ plots of pollucite. The dashed and solid line areas represent the compositions of pollucite inclusions published by Wang et al. (2004) and of homogeneous pollucite studied by Teertstra et al. (1992), respectively.

TABLE 5. REPRESENTATIVE ANALYSES OF DIFFERENT DOMAINS OF ZIRCON CRYSTALS FROM THE REPLACEMENT UNIT OF THE ÁNGEL PEGMATITE

\begin{tabular}{|c|c|c|c|c|c|c|c|c|c|c|c|c|}
\hline & \multicolumn{4}{|c|}{$\begin{array}{l}\text { Cores of Hf-poor zircon } \\
\qquad(n=9)\end{array}$} & \multicolumn{4}{|c|}{$\begin{array}{l}\text { Rims of hafnian zircon } \\
\qquad(n=15)\end{array}$} & \multicolumn{4}{|c|}{$\begin{array}{l}\text { Heterogeneous non-stoichiometric } \\
\text { zircon } \\
(n=9)\end{array}$} \\
\hline & Min & Max & Averag & Std Dev & Min & Max & Average & $\begin{array}{l}\text { Std } \\
\text { Dev }\end{array}$ & Min & Max & Ave-rac & e Std Dev \\
\hline $\mathrm{SiO}_{2}$ wt. $\%$ & 26.81 & 29.87 & 29.20 & 0.94 & 25.69 & 29.19 & 27.00 & 1.01 & 14.66 & 27.16 & 19.63 & 4.87 \\
\hline $\mathrm{P}_{2} \mathrm{O}_{5}$ & 0.08 & 1.9 & 0.45 & 0.55 & b.d.I. & 0.66 & 0.14 & 0.17 & 0.27 & 11.4 & 4.76 & 3.62 \\
\hline $\mathrm{Al}_{2} \mathrm{O}_{3}$ & b.d.l. & 0.13 & 0.03 & 0.04 & b.d.I. & 0.08 & 0.01 & 0.02 & b.d.I. & 0.89 & 0.61 & 0.33 \\
\hline $\mathrm{ZrO}_{2}$ & 55.59 & 58.06 & 56.31 & 0.78 & 42.03 & 51.37 & 44.71 & 3.11 & 42.22 & 52.8 & 47.04 & 3.02 \\
\hline $\mathrm{HfO}_{2}$ & 11.5 & 14.19 & 13.38 & 0.91 & 18.77 & 29.84 & 26.91 & 3.37 & 10.13 & 12.79 & 11.75 & 0.85 \\
\hline $\mathrm{CaO}$ & b.d.l. & 0.62 & 0.09 & 0.20 & b.d.I. & 0.23 & 0.05 & 0.05 & 0.16 & 3.33 & 1.36 & 0.97 \\
\hline $\mathrm{MnO}$ & b.d.I. & 0.37 & 0.07 & 0.11 & b.d.I. & 0.11 & 0.03 & 0.03 & 0.13 & 2.82 & 1.20 & 0.92 \\
\hline $\mathrm{Na}_{2} \mathrm{O}$ & b.d.I. & 0.33 & 0.04 & 0.11 & b.d.I. & b.d.I. & 0.00 & 0.00 & b.d.I. & 0.57 & 0.26 & 0.25 \\
\hline Total & 97.98 & 101.01 & 99.61 & 1.05 & 97.31 & 101.13 & 98.88 & 1.08 & 79.56 & 92.88 & 86.69 & 4.46 \\
\hline Si apfu & 0.89 & 0.97 & 0.96 & 0.02 & 0.93 & 0.98 & 0.95 & 0.01 & 0.52 & 0.96 & 0.74 & 0.16 \\
\hline $\mathrm{P}$ & 0.00 & 0.05 & 0.01 & 0.02 & 0.00 & 0.02 & 0.00 & 0.01 & 0.01 & 0.34 & 0.15 & 0.12 \\
\hline $\mathrm{Al}$ & 0.00 & 0.01 & 0.00 & 0.00 & 0.00 & 0.00 & 0.00 & 0.00 & 0.00 & 0.04 & 0.03 & 0.02 \\
\hline $\mathrm{Zr}$ & 0.89 & 0.93 & 0.90 & 0.01 & 0.73 & 0.84 & 0.77 & 0.03 & 0.78 & 0.91 & 0.87 & 0.04 \\
\hline $\mathrm{Hf}$ & 0.11 & 0.13 & 0.12 & 0.01 & 0.18 & 0.31 & 0.27 & 0.04 & 0.11 & 0.14 & 0.13 & 0.01 \\
\hline $\mathrm{Ca}$ & 0.00 & 0.02 & 0.00 & 0.01 & 0.00 & 0.01 & 0.00 & 0.00 & 0.01 & 0.13 & 0.06 & 0.04 \\
\hline $\mathrm{Mn}$ & 0.00 & 0.01 & 0.00 & 0.00 & 0.00 & 0.00 & 0.00 & 0.00 & 0.00 & 0.08 & 0.04 & 0.03 \\
\hline $\mathrm{Na}$ & 0.00 & 0.02 & 0.00 & 0.01 & 0.00 & 0.00 & 0.00 & 0.00 & 0.00 & 0.05 & 0.02 & 0.02 \\
\hline$\sum T$ site & 0.95 & 0.98 & 0.97 & 0.01 & 0.94 & 0.98 & 0.96 & 0.01 & 0.86 & 0.97 & 0.92 & 0.04 \\
\hline $\mathrm{Si} /(\mathrm{P}+\mathrm{Al})$ & 0.00 & 0.06 & 0.01 & 0.02 & 0.00 & 0.02 & 0.00 & 0.01 & 0.01 & 0.66 & 0.25 & 0.22 \\
\hline$\sum$ cations & 1.02 & 1.05 & 1.03 & 0.01 & 1.02 & 1.06 & 1.04 & 0.01 & 1.06 & 1.17 & 1.11 & 0.04 \\
\hline$(\mathrm{Zr}+\mathrm{Hf})$ & 1.01 & 1.04 & 1.02 & 0.01 & 1.02 & 1.06 & 1.04 & 0.01 & 0.90 & 1.04 & 0.99 & 0.04 \\
\hline $\mathrm{Hf} /(\mathrm{Zr}+\mathrm{Hf})$ & 0.10 & 0.13 & 0.12 & 0.01 & 0.18 & 0.29 & 0.26 & 0.04 & 0.11 & 0.14 & 0.13 & 0.01 \\
\hline
\end{tabular}

Formulae calculated based on 4 oxygen per formula unit. b.d.I. = below detection limit 
TABLE 6. REPRESENTATIVE ANALYSES OF POLLUCITE FROM THE REPLACEMENT UNIT OF THE ÁNGEL PEGMATITE

\begin{tabular}{|c|c|c|c|c|c|c|c|c|c|}
\hline & 1 & 2 & 3 & 4 & 5 & 6 & 7 & 8 & 9 \\
\hline $\mathrm{SiO}_{2}$ wt. $\%$ & 46.18 & 45.36 & 46.71 & 45.94 & 44.67 & 44.77 & 44.48 & 44.53 & 48.18 \\
\hline $\mathrm{Al}_{2} \mathrm{O}_{3}$ & 15.57 & 15.87 & 15.52 & 15.76 & 15.89 & 15.81 & 15.8 & 15.87 & 14.93 \\
\hline $\mathrm{P}_{2} \mathrm{O}_{5}$ & 0.26 & 0.27 & 0.15 & 0.11 & 0.15 & 0.24 & 0.25 & 0.36 & 0.17 \\
\hline $\mathrm{FeO}$ & 0.02 & 0.04 & b.d.I. & 0.17 & 0.01 & b.d.I. & b.d.l. & 0.01 & 0.06 \\
\hline $\mathrm{MnO}$ & b.d.I. & 0.01 & b.d.I. & 0.01 & 0.01 & 0.03 & 0.03 & 0.07 & b.d.l. \\
\hline $\mathrm{MgO}$ & 0.04 & b.d.I. & b.d.I. & b.d.I. & b.d.I. & b.d.I. & 0.04 & b.d.I. & b.d.l. \\
\hline $\mathrm{CaO}$ & b.d.I. & 0.02 & b.d.I. & 0.02 & b.d.I. & b.d.l. & b.d.I. & b.d.I. & b.d.I. \\
\hline $\mathrm{Na}_{2} \mathrm{O}$ & 1.79 & 1.84 & 1.81 & 1.8 & 1.84 & 2.00 & 1.93 & 1.87 & 1.81 \\
\hline $\mathrm{K}_{2} \mathrm{O}$ & 0.04 & 0.02 & 0.05 & 0.08 & b.d.I. & 0.01 & b.d.I. & 0.02 & b.d.l. \\
\hline $\mathrm{Rb}_{2} \mathrm{O}$ & 0.19 & 0.15 & 0.20 & 0.20 & 0.30 & 0.24 & 0.30 & 0.18 & 0.28 \\
\hline $\mathrm{Cs}_{2} \mathrm{O}$ & 36.56 & 37.81 & 37.39 & 36.78 & 37.08 & 36.92 & 37.14 & 37.15 & 35.92 \\
\hline TOTAL & 100.66 & 101.39 & 101.82 & 100.86 & 99.94 & 100.02 & 99.97 & 100.06 & 101.34 \\
\hline Si apfu & 2.13 & 2.10 & 2.14 & 2.12 & 2.10 & 2.10 & 2.09 & 2.09 & 2.18 \\
\hline $\mathrm{Al}$ & 0.85 & 0.87 & 0.84 & 0.86 & 0.88 & 0.87 & 0.88 & 0.88 & 0.80 \\
\hline$P$ & 0.01 & 0.01 & 0.01 & 0.00 & 0.01 & 0.01 & 0.01 & 0.01 & 0.01 \\
\hline$\sum T$ site & 2.99 & 2.98 & 2.98 & 2.98 & 2.99 & 2.98 & 2.98 & 2.98 & 2.98 \\
\hline $\mathrm{Fe}$ & 0.00 & 0.00 & 0.00 & 0.01 & 0.00 & 0.00 & 0.00 & 0.00 & 0.00 \\
\hline $\mathrm{Mn}$ & 0.00 & 0.00 & 0.00 & 0.00 & 0.00 & 0.00 & 0.00 & 0.00 & 0.00 \\
\hline $\mathrm{Mg}$ & 0.00 & 0.00 & 0.00 & 0.00 & 0.00 & 0.00 & 0.00 & 0.00 & 0.00 \\
\hline $\mathrm{Ca}$ & 0.00 & 0.00 & 0.00 & 0.00 & 0.00 & 0.00 & 0.00 & 0.00 & 0.00 \\
\hline $\mathrm{Na}$ & 0.16 & 0.17 & 0.16 & 0.16 & 0.17 & 0.18 & 0.18 & 0.17 & 0.16 \\
\hline $\mathrm{K}$ & 0.00 & 0.00 & 0.00 & 0.00 & 0.00 & 0.00 & 0.00 & 0.00 & 0.00 \\
\hline $\mathrm{Rb}$ & 0.01 & 0.00 & 0.01 & 0.01 & 0.01 & 0.01 & 0.01 & 0.01 & 0.01 \\
\hline Cs & 0.72 & 0.75 & 0.73 & 0.72 & 0.74 & 0.74 & 0.75 & 0.74 & 0.69 \\
\hline$\sum A$ site & 0.89 & 0.92 & 0.90 & 0.90 & 0.92 & 0.93 & 0.93 & 0.92 & 0.86 \\
\hline CRK & 81.70 & 81.90 & 82.14 & 81.92 & 81.77 & 80.40 & 80.83 & 81.51 & 81.53 \\
\hline $\mathrm{Si} / \mathrm{Al}$ & 2.52 & 2.42 & 2.55 & 2.47 & 2.38 & 2.40 & 2.39 & 2.38 & 2.74 \\
\hline
\end{tabular}

Formula calculated based on 6 oxygen per formula unit.

CRK is defined as the molar ratio of $(\mathrm{Cs}+\mathrm{Rb}+\mathrm{K}) /(\mathrm{Mg}+\mathrm{Ca}+\mathrm{Na}+\mathrm{Cs}+\mathrm{Rb}+\mathrm{K})($ Teertstra et al. 1992)

b.d.I. = below detection limit

ranges from 80.40 to 82.14 , and $\mathrm{Si} / \mathrm{Al}$ ranges from 2.38 to 2.74. These compositions are similar to those of the pollucite inclusions described by Wang et al. (2004), and to the compositions of the homogeneously textured pollucite grains studied by Teertstra et al. (1992).

\section{Other secondary phosphates minerals}

Several secondary phosphate mineral were recognized by means of BSE-SEM/EDS observations and electron microprobe analysis. Hydrothermal phosphate minerals like fluorapatite and lacroixite occur as inclusions in montebrasite, often following a fissure network. Endmember fluorapatite contains small amounts of Mn. Lacroixite is very common. In most grains the measured $\mathrm{Na}$ content is below $1.00 \mathrm{Na} a p f u$, and can be as low as $0.63 \mathrm{Na} a p f u$ (Table 1). In spite of the fact that we used mild conditions for the WDS analyses $(15 \mathrm{kV}, 5$ or 10 nA), Na migration cannot be disregarded, particularly as crystal size imposed a rather small beam diameter. Another likely possibility is that $\mathrm{Na}$ is partially replaced by $\mathrm{Li}$, as found for lacroixite from Gatumba (Rwanda) by Fransolet (1989). Calculation of the Li content as (1 - Na) apfu led to totals close to $100 \%$ when $(\mathrm{OH})$ was added to completely fill the F site (Table 1).

Supergene processes led to the alteration of the primary phosphate minerals, mainly montebrasite, and the kaolinization of primary feldspars. The most important supergene phosphate minerals, occurring as interstitial grains and patchy textured crystals, are Mn-rich chlorapatite, crandallite-goyazite, and other $\mathrm{Zr}, \mathrm{Hf}, \mathrm{Ca}, \mathrm{Sr}, \mathrm{Mn}$, and Al-bearing phosphate minerals (Demartis et al. unpublished data).

\section{DISCUSSION}

\section{Geochemical features of pegmatitic melts during primary stages}

Most pegmatites from the Comechingones pegmatite field display low to intermediate degrees of fractionation (Demartis 2010, Demartis et al. 2012), and Be-NbU-P-bearing minerals are restricted to a few bodies. London et al. (1999) found that the phosphorus content 
of the melt was buffered by the equilibrium between $\mathrm{Li}$ phosphates and silicates, according to the reaction

$$
\begin{aligned}
& \mathrm{LiAlSi}_{4} \mathrm{O}_{10}+\mathrm{PO}_{2}(\mathrm{OH}, \mathrm{F})(\mathrm{m})= \\
& \mathrm{LiAlPO}_{4}(\mathrm{OH}, \mathrm{F})+4 \mathrm{SiO}_{2}
\end{aligned}
$$

In the case of the Ángel pegmatite, in spite of the fact that muscovite probably incorporates some $\mathrm{Li}$, the bulk partition coefficient $\mathrm{Li}^{\text {solid/melt }}$ remained below 1 , producing Li buildup by fractional crystallization. The occurrence of primary phosphate minerals (triplitezwieselite and montebrasite) in some parts of the Ángel pegmatite, as described above, is evidence of early P enrichment of the pegmatitic melts (London et al. 1999). Therefore, the $\mathrm{P}$ content was high enough to exhaust the buffer capacity of the magma, so that only montebrasite is found, to the exclusion of Li aluminosilicate minerals (petalite or spodumene). The precipitation of montebrasite instead of $\mathrm{Li}$ aluminosilicate minerals could also be influenced by a relatively low temperature, as the solubility of $\mathrm{Li}$ phosphate minerals increases rapidly with this parameter. On the other hand, the formation of montebrasite instead of amblygonite (i.e., $\mathrm{OH}>\mathrm{F}$ ) suggests that $\mathrm{F}$ activity was low during these stages (London \& Burt, 1982). Applying the equation presented by London et al. (2001), the concentration of $\mathrm{F}$ in the melt was around $1.4 \mathrm{wt} . \% \mathrm{~F}$ (using an average value of $5.34 \mathrm{wt} . \% \mathrm{~F}$ in montebrasite, $n=13$ ).

The occurrence of the replacement unit with complex mineral associations which include F-Li-Cs$\mathrm{Rb}$-Ta-Hf suggests the existence of late, extremely evolved fluids. In fact, the composite nature of the pegmatite dykes from the Comechingones field, briefly described above and more extensively explained by Demartis et al. (2011), evidences a constant input of multiple batches of pegmatitic melts and fluids, probably from a common parent source that ascended from lower portions of the crust, enhanced by synmagmatic deformation (the GCSZ deformation), and emplaced beside each other to form larger, tabular composite pegmatites. According to this emplacement model, the replacement unit of the Ángel pegmatite originally formed as a lens-shaped pegmatite with an intermediate to high degree of fractionation (evidenced by the occurrence of montebrasite and the relatively high $\mathrm{F}$ concentration in the melt) emplaced beside other, less fractionated, pegmatite sheets. These field observations indicate an ongoing geochemical evolution of the pegmatitic source, not exposed at the present erosion level, which would probably generate progressively more fractionated pegmatitic melts that escaped via the ascent and emplacement mechanisms proposed by Demartis et al. (2011).

\section{Extreme enrichment in volatile components, LIL and HFS elements during metasomatism}

Textural evidence (Figs. 4b-f), along with the lack of internal zoning at outcrop scale and heterogeneous mineral distribution (Fig. 2b), suggest a pervasive metasomatic replacement of the previously formed mineral assemblage 1, and the consequent crystallization of new, secondary minerals, such as albite, Cs-, Rb-, and F-rich micas and other minerals from assemblage 2. The strongly foliated fabric of the rocks constituting the replacement unit also accounts for a syn-deformational origin of the metasomatic events. The occurrence of relict microcline from earlier assemblages suggests that muscovite formed at the expense of microcline via a subsolidus metasomatic process, as was established by Černý et al. (1985) for lepidolite unit consolidation in lepidolite-type pegmatites.

The main compositional changes during this metasomatic replacement are the $\mathrm{F}$ and $\mathrm{Cs}$ enrichment of the system. The progressive increase in $\mathrm{F}$ activity caused the crystallization of micas with anomalously high $\mathrm{F}$ contents, allowing the occurrence of poorly reported or unreported mineral compositions, such as those of sokolovaite and the F-analogues of muscovite and nanpingite.

Experimental studies reported by London et al. (1988) and Borodulin et al. (2009) for peraluminous granitic melts indicate that $F$ remains preferentially in the melt rather than in the fluid phase, since vapor/melt partition coefficients range between 0.1 and 0.7 . In addition, minerals belonging to the primary assemblage do not indicate a very high $\mathrm{F}$ activity $[$ e.g., $\mathrm{F} /(\mathrm{F}+\mathrm{OH})$ ratios of 0.35-0.44 in montebrasite]. Therefore, progressive fractionation of $\mathrm{F}$ during magmatic stages and further exsolution of a highly evolved F-rich magmatic fluid cannot be a plausible explanation, since $\mathrm{F}$ partitions preferentially into the melt. Furthermore, if $\mathrm{F}$ accumulation in the melt due to fractional crystallization occurs, amblygonite should predominate in the mineral assemblage 1, instead of montebrasite.

Alternatively, a supercritical transition from silicate melt to aqueous fluid leading to metasomatic replacement is proposed to explain the $\mathrm{F}$ enrichment (London 2005). The fluid phase causing metasomatism would actually represent the last residual melt that behaved as a supercritical fluid phase with complete miscibility between silicate melt and fluid (Sowerby \& Keppler 2002).

The extreme fractionation of the replacement unit and its Cs enrichment is evidenced by the crystallization of pollucite and Cs micas. Unlike the pegmatites found at Red Cross Lake, Canada (Černý et al. 2012), our pollucite does not show signs of alteration, and is probably not the Cs source for the metasomatic fluids, but rather a consequence of this enrichment. High Cs 
activity is also evidenced by the crystallization of sokolovaite and the F-analogue of nanpingite along fissures and crystal rims. This contrasts with the Cs micas from the Eastern Moblan granitic pegmatite, Quebec, Canadá (Potter et al. 2009), which were interpreted to result from the progressive Cs enrichment of zoned muscovite.

The replacement of the previously existing minerals (from the first and second mineral assemblages) and the crystallization of such a F-rich mineral association resulted in the removal of $\mathrm{F}$ from the solution. The solubility of some incompatible elements in granitic melts is increased by F complexation (Linnen 1998, Bartels et al. 2010, Van Lichtervelde et al. 2010, Linnen et al. 2012). The drop of F activity in the solutions probably controlled the precipitation of $\mathrm{Ta}, \mathrm{U}, \mathrm{Bi}, \mathrm{Hf}, \mathrm{Rb}, \mathrm{Cs}$, and $\mathrm{Li}$, as reflected by the mineral chemistry of the metasomatic assemblages found in the replacement unit of the Ángel pegmatite.

\section{CONCLUSIONS}

Pegmatites of the CPF display low to intermediate degrees of fractionation. However, the syntectonic emplacement of these pegmatites in a large shear zone favored the migration of late evolved fluids, enriched in highly incompatible elements, such as LILE and HFSE. The enrichment of $\mathrm{F}$ in these fluids favored the replacement of selected pegmatitic lenses in an acidic context. The $\mathrm{F}$ activity in these fluids increased progressively with time, as recorded by the mineral associations: montebrasite, F-rich muscovite in the early stages of the replacement, and micas with $\mathrm{F}$ as the dominant volatile in the late stages. These extreme F enrichments may account for the crystallization of $\mathrm{F}$-analogues of muscovite and sokolovaite and other rare F-dominant micas never previously reported, such as the F-analogue of nanpingite. After the removal of $\mathrm{F}$ from the system, the solubility of several Ta-, U-, Bi-, Hf-, Cs-, and Li-bearing minerals could have been strongly modified, thus allowing their precipitation during the later stages of metasomatic activity.

\section{ACKNOWLEDGEMENTS}

The authors want to thank Editor Lee A. Groat, Guest Editor Carl Francis, and an anonymous reviewer for their comments on the manuscript, and the Managing Editor, Mackenzie Parker, for the editing review. Fernando Colombo thanks LAMARX-FAMAF, Universidad Nacional de Córdoba, for access to the microprobe. The study was financed by the Agencia de Promoción Científica y Técnica (ANPCyT, projects PICT 0362/2011 and PICT 1477/2008), SeCyT-Universidad Nacional de Río Cuarto (program 18/C 360) and CONICET (PIP CONICET- 0916). Analytical data were also financed by the Grupo Consolidado de Investigación SGR 444, Generalitat de Catalunya, Spain.

\section{REFERENCES}

Angelelli, V. (1950) Recursos minerales de la República Argentina, I. Yacimientos Metalíferos. Revista del Instituto Nacional de Investigaciones de las Ciencias Naturales 'Bernardino Rivadavia', Serie Ciencias Geológicas 2, $1-543$.

Atencio, D., Andrade, M.B., Christy, A.G., Gieré, R., \& Kartashov, P.M. (2010) The pyrochlore supergroup of minerals: nomenclature. Canadian Mineralogist 48, 673-698.

Bartels, A., Holtz, F., \& Linnen, R.L. (2010) Solubility of manganotantalite and manganocolumbite in pegmatitic melts. American Mineralogist 95, 537-544.

Borodulin, G.P., Chevychelov, V.Yu., \& Zaraysky, G.P. (2009) Experimental study of partitioning of tantalum, niobium, manganese, and fluorine between aqueous fluoride fluid and granitic and alkaline melts. Doklady Earth Sciences 427(1), 868-873.

Bosi, F., Skogby, H., Agrosì, G., \& Scandale, E. (2012) Tsilaisite, $\mathrm{NaMn}_{3} \mathrm{Al}_{6}\left(\mathrm{Si}_{6} \mathrm{O}_{18}\right)\left(\mathrm{BO}_{3}\right)_{3}(\mathrm{OH})_{3} \mathrm{OH}$, a new mineral species of the tourmaline supergroup from Grotta d'Oggi, San Pietro in Campo, island of Elba, Italy. American Mineralogist 97, 989-994.

ČERNÝ, P. (1989) Characteristics of pegmatite deposits of tantalum. In Lanthanides, Tantalum and Niobium (P. Möller, P. Černý, \& F. Saupé, eds.). Springer-Verlag, Berlin, Germany (195-239).

Černý, P., Meintzer, R.E., \& Anderson, A.J. (1985) Extreme fractionation in rare-element granitic pegmatites: selected examples of data and mechanisms. Canadian Mineralogist 23, 381-421.

Černý, P., Teerstra, D.K., Chapman, R., Selway, J., Hawthorne, F.C., Ferreira, K., Chackowsky, L.E., Wang, X.-J., \& MEINTZER, R.E. (2012) Extreme fractionation and deformation of the leucogranite-pegmatite suite at Red Cross Lake, Manitoba, Canada, IV. Mineralogy. Canadian Mineralogist 50, 1839-1875.

Correia Neves, J.M., Lopes Nunes, J.E., \& Sahama, Th.G. (1974) High hafnium members of the zircon-hafnon series from the granite pegmatites of Zambézia, Mozambique. Contributions to Mineralogy and Petrology 48(1), 73-80

Demartis, M. (2010) Emplazamiento y petrogénesis de las pegmatitas y granitoides asociados. Sector central de la Sierra de Comechingones, Córdoba, Argentina. Ph.D. thesis, Universidad Nacional de Río Cuarto, Argentina, 265.

Demartis, M., Pinotti, L.P., Coniglio, J.E., D’Eramo, F.J., Tubía, J.M., Aragón, E., \& Agulleiro Insúa, L.A. (2011) Ascent and emplacement of pegmatitic melts in a major reverse shear zone (Sierras de Córdoba, Argentina). Journal of Structural Geology 33(9), 1334-1346.

Demartis, M., Aragón, E., Coniglio, J.E., Pinotti, L.P., D’Eramo, F.J., Agulleiro Insúa, L.A., MafFini, M.N., 
\& Petrelli, H.A. (2012) Geoquímica y metalogénesis de las pegmatitas y granitos asociados del sector sur del distrito Comechingones, Córdoba. Serie Correlación Geológica 28(1), 103-116.

Fagiano, M. (2007) Geología y Petrología del basamento cristalino de Las Albahacas, sur de la Sierra de Comechingones, Córdoba. Ph.D. thesis, Universidad Nacional de Río Cuarto, Argentina, 380.

FrANSOLET, A.-M. (1989) The problem of Na-Li substitution in primary $\mathrm{Li}-\mathrm{Al}$ phosphates: new data on lacroixite, a relatively widespread mineral. Canadian Mineralogist 27, 211-217.

Galliski, M. (1994) La Provincia Pegmatítica Pampeana. I: Tipología y distribución de sus distritos económicos. Revista de la Asociación Geológica Argentina 49(1-2), 99-112.

Gonçalves, A.O., Melgarejo, J.C., \& Alfonso, P. (2009) Sequence of crystallisation of pegmatites: the Angola case. Estudos Geologicos 19(2), 35-39.

Henry, D.J., Nóvak, M., Hawthorne, F.C., Ertl, A., Dutrow, B., Uher, P., \& Pezzotta, F. (2011) Nomenclature of the tourmaline-supergroup minerals. American Mineralogist 96, 895-913.

HuB, C.C. (1994) Estudio geológico-económico de pegmatitas del Distrito Comechingones. Informe beca CONICOR, Córdoba province, Argentina, 156.

HuB, C.C. (1995) Estudio geológico-económico de pegmatitas del Distrito Comechingones. Informe beca CONICOR, Córdoba province, Argentina, 172.

KonTAK, D.J. (2006) Nature and origin of an LCT-suite pegmatite with late-stage sodium enrichment, Brazil Lake, Yarmouth County, Nova Scotia. I. Geological setting and petrology. Canadian Mineralogist 44, 563-598.

Linnen, R.L. (1998) The solubility of Nb-Ta-Zr-Hf-W in granitic melts with $\mathrm{Li}$ and $\mathrm{Li}+\mathrm{F}$ : Constraints for mineralization in rare metal granites and pegmatites. Economic Geology 93, 1013-1025.

LinNen, R.L., VAn Lichtervelde, M., \& ČERnÝ, P. (2012) - Granitic pegmatites as sources of strategic metals. Elements 8, 275-280.

LONDON, D. (2005) Granitic pegmatites: an assessment of current concepts and directions for the future. Lithos $\mathbf{8 0}$, 281-303.

LONDON, D. \& BuRT, D.M. (1982) Chemical models for lithium aluminosilicate stabilities in pegmatites and granites. American Mineralogist 67, 494-509.

London, D., Hervig, R.L., \& Morgan, G.B., VI. (1988) Melt-vapor solubilities and elemental partitioning in peraluminous granite-pegmatite systems: Experimental results with Macusani glass at $200 \mathrm{MPa}$. Contributions to Mineralogy and Petrology 99, 360-373.
London, D., Morgan, G.B., VI, \& Wolf, M.B. (2001) Amblygonite-montebrasite solid solutions as monitors of fluorine in evolved granitic and pegmatitic melts. American Mineralogist 86, 225-233.

London, D., Wolf, M.B., Morgan, G.B., VI, \& Gallego GARRIDO, M. (1999) Experimental silicate-phosphate equilibria in peraluminous granitic magmas, with a case study of the Alburquerque batholith at Tres Arroyos, Badajoz, Spain. Journal of Petrology 40(1), 215-240.

Martino, R. (2003) Las fajas de deformación dúctil de las Sierras Pampeanas de Córdoba: Una reseña general. Revista de la Asociación Geológica Argentina 58 , 549-571.

Ni, Y. \& Hughes, J.M. (1996) The crystal structure of nanpingite- $2 \mathrm{M}_{2}$, the Cs end-member of muscovite. American Mineralogist 81, 105-110.

Otamendi, J.E., Castelarini, P.A., Fagiano, M., Demichelis, A., \& Tibaldi, A. (2004) Cambrian to Devonian geologic evolution of the Sierra de Comechingones, eastern Sierras Pampeanas: evidence for the development and exhumation of continental crust on the proto-Pacific margin of Gondwana. Gondwana Research 7(4), 1143-1155.

Pautov, L.A., Agakhanov, A.A., \& Bekenova, G.K. (2006) Sokolovaite $\mathrm{CsLi}_{2} \mathrm{AlSi}_{4} \mathrm{O}_{10} \mathrm{~F}_{2}$ - a new mineral species of the mica group. New Data on Minerals 41, 5-13.

Pinotti, L.P, Tubía, J.M., D’Eramo, F.J, Vegas, N., Sato, A.M, Coniglio, J.E., \& Aranguren, A. (2006) Structural interplay between plutons during the construction of a batholith (Cerro Aspero batholith, Sierras de Córdoba, Argentina). Journal of Structural Geology 28(5), 834-849.

Pointer, C.M., Ashworth, J.R., \& Ixer, R.A. (1988) The zircon-thorite mineral group in metasomatized granite, Ririwai, Nigeria. 2. Zoning, alteration and exsolution in zircon. Mineralogy and Petrology 39, 21-37.

Potter, E.G., Taylor, R.P., Jones, P.C., Lalonde, A.E., PeArse, G.H.K., \& Rowe, R. (2009) Sokolovaite and evolved lithian micas from the Eastern Moblan granitic pegmatite, Opatica subprovince, Quebec, Canada. Canadian Mineralogist 47, 337-349.

Rapela, C.W., Pankhurst R.J., Casquet, C., Baldo, E. SaAvedra, J., Galindo, C., \& Fanning, C.M. (1998) The Pampean orogeny of the southern proto-Andes: Cambrian continental collision in the Sierras de Córdoba. In The Proto-Andean Margin of Gondwana (R.J. Pankhurst \& C.W. Rapela, eds.). Geological Society, London, Special Publication 142, 181-217.

RigaL, R. (1938) Las minas de columbita y tantalita y el descubrimiento de minerales de uranio radioactivos en la Cañada de Álvarez (dpto. Calamuchita), Córdoba. Dirección de Minas y Geología, Boletín 45

Selway, J.B. \& JiAng XIONG (2002) Tourmaline-recalculation software quoted in Tindle et al. (2002). http://www.open ac.uk/earth-research/tindle/AGTWebPages/AGTSoft.html 
Sims, J.P., Ireland, T.R., Camacho, A., Lyons, P., Pieters, P.E., Skirrow, R.G., \& Stuart-Smith, P.G. (1998) U-Pb, $\mathrm{Th}-\mathrm{Pb}$ and $\mathrm{Ar}-\mathrm{Ar}$ geochronology from the southern Sierras Pampeanas, Argentina: implications for the Palaeozoic tectonic evolution of the western Gondwana margin. In The Proto-Andean Margin of Gondwana (R.J. Pankhurst \& C.W. Rapela, eds.). Geological Society, London, Special Publication 142, 259-281.

Sowerby, J.R. \& KePpler, H. (2002) The effect of fluorine, boron, and excess sodium on the critical curve in the albite- $\mathrm{H}_{2} \mathrm{O}$ system. Contributions to Mineralogy and Petrology 143, 32-37.

Steenken, A., Wemmer, K., Martino, R.D., López De Luchi, M.G., Guereschi, A., \& Siegesmund, S. (2010) Post-Pampean cooling and the uplift of the Sierras Pampeanas in the west of Córdoba (Central Argentina). Neues Jahrbuch für Geologie und Paläontologie, Abhandlungen 256(2), 235-255.

Teertstra, D.K., Černý, P., \& Chapman, R. (1992) Compositional heterogeneity of pollucite from High Grade Dyke, Maskwa Lake, southeastern Manitoba. Canadian Mineralogist 30, 687-697.

VAn Lichtervelde, M., Holtz, F., \& Hanchar, J.M. (2010) Solubility of manganotantalite, zircon and hafnon in highly fluxed peralkaline to peraluminous pegmatitic melts. Contributions to Mineralogy and Petrology 160, 17-32.

Van Lichtervelde, M., Salvi, S., Beziat, D., \& Linnen, R.L. (2007) Textural features and chemical evolution in tantalum oxides: Magmatic versus hydrothermal origins for Ta mineralization in the Tanco Lower Pegmatite, Manitoba, Canada. Economic Geology 102, 257-276.

Wang, R.C., Hu, H., Zhang, A.C., Huang, X.L., \& Ni, P. (2004) Pollucite and the cesium-dominant analogue of polylithionite as expressions of extreme Cs enrichment in the Yichun topaz-lepidolite granite, southern China. Canadian Mineralogist 42, 883-896.

Whitmeyer, S.J. \& Simpson, C. (2003) High strain-rate deformation fabrics characterize a kilometers-thick Paleozoic fault zone in the Eastern Sierras Pampeanas, central Argentina. Journal of Structural Geology 25(6), 909-922.

Wise, M.A., Francis, C.A., \& ČernÝ, P. (2012) Compositional and structural variations in columbite-group minerals from granitic pegmatites of the Brunswick and Oxford fields, Maine: differential trends in F-poor and F-rich environments. Canadian Mineralogist 50(6), 1515-1530.

Received December 20, 2013. Accepted March 25, 2014. 
